\title{
日本地学史文献集
}

\author{
附 海外関 係 文献 \\ 日本地学史資料調査委員会

\section{Bibliography of History of Japanese Earth Sciences} \section{Japanese Earth Science} \\ Compiled by Committee for History of
}

\section{Tokyo Geographical Society}

はじめに

日本地学史資料調查委員会は，1972年以来，地 学史に関する資料の実態調査や文献の整理にあた つている。本稿は，その一環として，とりあえず 日本の地学史に関する文献を項目別, 年代順に整 理したものである。参考として, 海外の関係文献 も若干収録した。

掲載文献は，それぞれの分野において通史的な ものを主とし, 史料・原典・文献目録・個人の伝 記や業績に関するものは，原則としては除外し た。これらについては今後整理し, 逐次追加して いく予定である。ただし, 東アジアの地学史に関 する文献目録は加えた。これはすでに入手困難と なつた文献が多く含まれているからである。文献
の分類上の扱いや取捨選択については，もちろん 相異なる見方むあるが，広く利用されるための便 宜を考光，また原則に対する多少の例外も認める ことにした。

本稿は短期間にまとめたために不十分なものと なつたが，今後充実した文献集を完成させるため の第一歩として，あえて公表するしだいである。 これを完成するために, 各方面からのご助言, ご 教示を扔願いする。この文献集の作成にあたつて は，本委員会が1972年に抗こなたアンケートも 参考にした。それのみならず，この編集作業につ いてもすでに種々のご協力をいただいているの で,この機にこれらの各位に厚く御礼申し上げる。 1976年 3 月

東京地学協会日本地学史資料調查委員会

\section{凡例}

1. 文献の収録範囲は, 日本の地学史に関する国内出版物（単行本，雑誌など）を主とし, 関連する外国出版物も若干含めた。

2. 地学の分野を次の10項目に分類した。
（1）地質 鉱物 古生物.$\cdots \cdots \cdots \ldots \ldots \ldots \ldots$

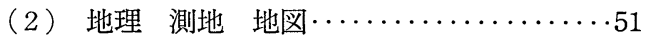
（3）地震 火山 地球物理.......... .55

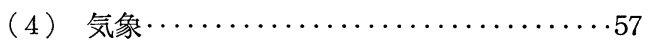

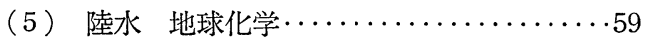

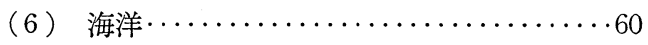

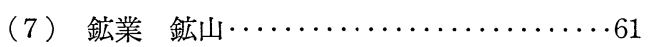

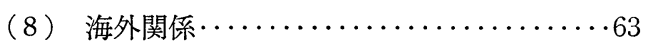
（9）地学教育 地学全般 $\cdots \cdots \cdots \cdots \cdots \cdots \cdots$ 
（10）科学史一般 大学関係 博物館など $\cdots \cdots 67$

各項目中では，文献を年代順に配列した。

3. 文献の記載要領

(1) 単行本

発行年, 著者名, 題名（カギかつこをつける）, 出版者名, 頁数の順

例） 1948 望月勝海:「日本地学史」. 平凡社全書, $184 \mathrm{p}$.

(2) 単行本中の独立論文

発行年, 著者名, 論文題名, 単行本の題名, 出版者名, 論文掲載頁の順

例） 1970 早坂一郎：大正時代の日本の古生物学史（覚え書き）.「日本古生物学の回 想」, 日本古生物学会, p. 34-52.

1970 NANBU, M.: Brief History of Descriptive Mineralogy in Japan.

"Introduction to Japanese Minerals" (Organizing Committee IMAIAGOD Meeting '70), Geol. Surv. Japan, p. 1-5.

（3）逐次刊行物（雑誌，紀要など）掲載論文 発行年, 著者名, 論文題名, 掲載誌名, 巻, 号, 頁の順

例） 1930 高木菊三郎：我国に於ける地形図製作の略史. 地球，Vol. 14，No. 2, p. 27-36.

1917 YABE, H. : Problems Concerning the Geotectonics of the Japanese Islands. Sci. Rept., Tohoku Imp. Univ., [2], Geol., Vol. 4, p. 75-104.

\section{I. 地質 - 鉱物 - 古生物}

1883 冨士谷孝雄 : 本邦石学一斑. 学芸志林, Vol. 12, No. 71, p. 506-513.

1884 山陰一生：地質調查事業進歩の景況. 東洋学芸雑誌, No. 35, p. 152-154.

1886 中島謙造 : 本邦地学沿革史. 地学会誌, 甲部, 第一輯, 第二輯, 第三輯.

1890 「地質局事業十年間報告」. 農商務省, 76 p.

1903 神保小虎 : 我国に於ける鉱物学の歴史. 地質学雑誌, Vol. 10, p. 442-450.

1904 和田維四郎 : 鉱物学の発達.「日本鉱物誌」, p. 1-8.

1905 神保小虎：本邦に於ける地質学の歴史. 地質学雑誌, Vol. 12, No. 147, p. 393-405.

1910 井上嘻之助：地質調査所の沿革及び事業. 地質調查所報告, No. 3, 120 p.

1916 徳田貞一 : 東京帝国大学地質学教室卒業論文及進級論文. 地質学雑誌, Vol. 23, No. 269, p. 90-95. 付困 1 枚 (明治12年〜大正 5 年の全論文の一覧).

1917 YABE, H.: Problems Concerning the Geotectonics of the Japanese Islands ; Critical reviews of various opinions expressed by previous authors on the geotectonics. Sci. Rept,

Tohoku Imp. Univ., [2], Geol., Vol. 4, p. 75-104.

1918 「東京地質学会創立二十五年記念展覧会目録」.

1926 Kanehara, N.: Geology of Japan. "Scientific Japan, Past and Present", Third Pan-Pacific Science Congress, Tokyo, p. 55-72.

1927 斉東野人：明治大正日本地質学の回顧. 科学画報 (特集日本の科学界), Vol. 9, No. 6, p. 129-137.

1927 渡辺萬次郎：本邦岩石鉱物学の発達。科学画報 (特集日本の科学界), Vol. 9, No. 6, p. 165171.

1927 大谷寿雄 : 造山論の史的瞥見とナウマン・ジュース・リヒトホーフェン. 東洋学芸雑誌, Vol. 
43 , No. 530 , p. $338-348$.

1930 横山又次郎 : 半百年前の思出. 地学雑誌, Vol. 42, No. 495, p. 252-258.

1933 加藤武夫 :「万国地質学会議」. 岩波講座, 地質学及び古生物学 砬物学及び岩石学, (別項), $39 \mathrm{p}$.

1936 岡本要八郎：明治初期金石学時代の図書(1)，(2). 我等の鉱物, Vol. 5, No. 11, p. 363-369.

No. 12 , p. 389-406.

1937 後閑文之助：上代日本鉱物学の变遷に就て. 地質学雑誌, Vol. 44, No. 525, p. 468-470.

1938 後閑文之助：上世より近世に至る日本鉱物学に及ぼした支那鉱物学の影響（I ）, (II). 科学,

Vol. 8, No. 8, p. 337-340. No. 10, p. 432-435.

1938 後閑文之助：享保より慶応に至る日本砋物学の変遷に就て。地質学雑誌, Vol. 45, No. 537, p. $460-461$.

1938 後閑文之助 : 江戸時代に於ける龍骨論争の史的研究。地質学雑誌, Vol. 45, No. 541, p. 105108.

1939 後閑文之助 : 江戸時代に於ける西洋人の日本鉱物地質考察の史的研究. 地質学雑誌，Vol. 46, No. 549 , p. 292-293.

1939 後閑文之助 : 近世における西洋釷物学地質学の日本に及ぼした影響 (I). 東京科学博物館研究 報告, No. 1, p. 53-104.

1939 YABE, H. : Recent Progress in Paleontology in the Japanese Empire. Proc. Sixth Pacif. Sci. Congr. p. 451-458.

1943 木下象城: 黎明期の日本鉱物に関する図書. 学鐙 (丸善), Vol. 47, No. 5, p. 11-14.

1943 北大理学部地質学鉱物学教室編 : 「北海道地質学関係事項年表 自寛永 12 年 (2295) 至昭和 18

年 $(2603)\rfloor .8 \mathrm{p}$.

1947 後閑文之助：地球の円いのを日本人が認識する迄. 地球の科学, Vol. 2, No. 3, p. 14-18.

1947 小林貞一：日米地学戦前戦後. アメリカ文化, Vol. 2, No. 7, p. 31-33.

1948 望月勝海 :「日本地学史」. 平凡社全書, $184 \mathrm{p}$.

1953 日本地質学会編：「日本地質学会史」一日本地質学会60周年記念一. 日本地質学会, $185 \mathrm{p}$.

日本地質学史 (略史, 年表, 部会史), 歷代会長名・評議員名・受賞者名, 明治時代の日本にお ける地質学, 扔もいで, 追悼, 各大学研究室・博物館・研究所・関係学会・団体等の歷史, 外 地に扔ける地質研究機関の歷史, 関係会社の地質調查研究史などを含む.

1953 早坂一郎：日本地質学会60年略史. 日本地質学会編「日本地質学会史」, p. 1-3.

1953 日本地質学会史年表. 日本地質学会編「日本地質学会史」, p. 4-29.

1953 矢部長克：明治時代の日本に打ける地質学. 日本地質学会編「日本地質学会史」, p. 36-44.

1953 輝く茨の道. 地球科学, No. 12 , p. 3-10.

1953 渡辺光明：現代日本科学技術史年表一地質鉱物学 (1)一. 科学史研究, No. 25, p. 17-22.

1954 多田文男 : 関東ローム層の研究史. 地球科学, No. 16, p. 10-11.

1954 山根新次・三土知芳 : わが国の地質調查事業の沿革. 地学雑誌, Vol. 63, No. 3, p. 47-61.

1954 原田準平: 明治以後の鉱物学界. 地学雑誌, Vol. 63, No. 3, p. 62-71.

1952 54 湊正雄: 本邦古生代層の研究 (1), (2), (3). 北海道地質要報, No. 19, p. 1-25. No. 24, p. 1-12. No. 26 , p. 1-9.

1955 岡田陽一: 東京大学最初の地学実習旅行と猫精のこと. 地学研究, Vol. 7, No. 5, p. 187-194.

1955 岡田陽一: 金石学々砿物学. 地学研究, Vol. 8, No. 1, p. 30-35.

1956 KANEKo, K.: Japon. Lexique Stratigraphique International, Vol. III, Asie, Fasicule 
3a, 163 p. 1 map.

1956 Hanzawa, S.: Ryu-Kyu. Ibid. Fasc. 3 b, p. 168-182. 1 table.

1956 湊正雄 : 本邦変成帯形成の時期に対する諸説。「鈴木醇教授還暦記念論文集」, p. 1-16.

1956 渡辺武男編 :「鉱床学の進歩」。冨山房, $581 \mathrm{p}$.

1956 渡辺萬次郎 : 加藤博士と本邦鉱床学の進歩. 「本邦鉱床学の進歩」, 冨山房, p. 562-567.

1956 福富忠男 : 鉱床学の進歩と加藤教授の研究。「本邦鉱床学の進歩」, 富山房, p. 568-572.

1958 地球科学編集部編: 東北日本と西南日本一その研究史と問題点. 地球科学, No. 37, p. 1-6.

1958 小林英夫 : 日本地質学史断片. 地球科学, No. 40, p. 21-27.

1958 61 斉藤仁 : 北海道の地下資源調查事業の沿革. 地下資源, No. 1-12.

1960 小林貞一 : 万国地層名辞典と漢字属名の Original Romanization について. 地質学雑誌, Vol.

63, No. 747 , p. $721-723$.

1961 Kobayashi, T.: Modern Progress of Geology in Japan. Jour. Geogr. Tokyo., Vol. 70, p. 209-214.

1961 小林貞一 : 国際古生物学会議. 化石, No. 2, p. 57-60.

1961 日本鉱山地質学会10周年記念特別号. 鉱山地質, Vol. 11, No. 45-46, 412 p. +63 p.

1961 渡辺武男 : わが国の金属鉱床研究の変遷（明治初期 $\rightarrow 1950$ 年まで）。鉱山地質，Vol. 11，No.

45-46, p. 3-6.

1961 土井正民：別子鉱床の成因論の変遷. 鉱山地質, Vol. 11, No. 45-46, p. 151-156.

1961 渡辺萬次郎 : 本邦金属鉱床学界の 2，3 の回雇頁。鉱山地質, Vol. 11, No. 45-46, p. 404-406.

1961 鈴木醇 : 四国キースラーガー調查の思い出. 鉱山地質, Vol. 11, No. 45-46, p. 408-410.

1961 兼子勝 : 学会誌「釷山地質」雑感。鉱山地質, Vol. 11, No. 45-46, p. 410-412.

1961 土井正民 : 別子付近の三波川変成帯とこれに伴ら含銅硫化鉄鉣鉣床 (1)一その研究の 史的変遷 と現況について. 鉱山地質, Vol. 11, No. 50, p. 610-626.

1961 仁田勇 : X線回折の50年. 科学, Vol. 31 , No. 9, p. 470-475.

1961 渡辺直経： $\mathrm{C}^{14}$ による年代測定 10 年の歩み. 科学, Vol. 31, No. 4, p. 204.

1961 池辺展生：日本の新生代地史の研究史.「槙山次郎教授記念論文集」, p. 339-342.

1961 KoBAYASHI, T.: Address to the Twenty-Fifth Anniversary of the Palaeontological

Society of Japan. Trans. Proc. Palaeonts. Soc. Japan, N.S., No. 41, p. 45-47.

1962 「地質調查所略史」(80周年記念出版物). 地質調查所, $56 \mathrm{p}$.

1962 地質調查所年表.「地質調查所略史」, p. 1-32.

1962 山根新次 : 地質調查所事業の変遷.「地質調查所略史」, p. 33-46.

1962 根本忠寛：地質調查所と北海道の地質調查史.「地質調查所略史」, p. 47-49.

1962 小林貞一 : 地質調查所創立 80 周年を祝して一この機会に世界の 地質調查所の創設を省夕る.

「地質調查所略史」, p. 50-55.

1962 小林貞一 : 日本地質構造研究史概観・日本造構史の探究・日本地質学最近の進歩. 日本地方地

質誌「総諭」堌補版，朝倉書店，p. 6-12，301-302，345-353.

1962 小林貞一: 太平洋学術会議と太平洋の地質. 地学雑誌, Vol. 71, No. 6, p. 32-36.

1962 小林貞一：国際地学連合 (IUGS) と万国地質学会議 (IGC). 地学雑誌, Vol. 71, No. 4, p. 192-194.

1962 「懐古録」. 地質調查所, $276 \mathrm{p}$.

1962 都城秋穗: 岩石学の歴史にお污る四つの段階とわが国の現状，地質学の諸問題，第 2 集，研究 課題シンポジウム, 日本地質学会. p. 13-27. 
1962 今井功：地質図幅調查事業の歴史. 地質ニュース, No. 98, p. 4-14.

1962 都城秋穂・坪井誠太郎：対談 風雪に耐え岩石にかじりっいての 40年. 科学読売, No. $2, \mathrm{p}$. 99-106.

1962 65 佐々保雄: 北海道地質図変遷史 (一), (二), (三). 北方文化研究報告, 第17輯, p. 1-38. 第19輯, p. 23-58. 第20輯, p. 153-221.

1963 小林貞一 : International Commission for the Lexicon of Stratigraphy. 化石, No. 6, p. 52.

1963 Matsushita, S. : Historical Review of the Geological Research in Japan. “ Geology of Japan" (TAKAi, F. MAtsumoto, T. and ToRiYAma, R. ed.), The University of Tokyo Press, p. 5-14.

1963 HanaI, T. and Konishi, K. : List of Fossil Subgenera, Genera and Higher Texa

Proposed through Japanese Publications. Ibid. p. 235-353.

1963 中野光雄 : 三角介類研究史の概略. 愛媛の地学, No. 2, p. 9-10.

1963 青山信雄 : 明治初期の鉱物学書. 地学研究, Vol. 13, No. 12, p. 343.

1963 64 木村正：金属鉱床探査の歩みと現況 1，2，3. 地質ニュース， No. 111，p. 1-13. No. 113 , p. $2-10$. No. 115 , p. 10-18.

1964 矢部長克・井尻正二 (対談)：日本の地質学と古生物学. 科学, Vol. 34, No. 11, p. 584-590. 1965 都城秋穂 : 地球科学の歴史と現状 (2)一日本における地球科学の成立一. 自然, No. 10, p. 79-87.

1965 都城秋穂 : わが国における変成岩の研究史.「変成岩と変成帯」, 岩波書店, p. 47-52.

1966 渡辺武男 : 黒鈗鉱床 その開発と研究発展との関連. 科学, Vol. 36, No. 2, p. 70-80.

1966 今井功 :「黎明期の日本地質学」. 地下の科学シリーズ 7, ラテイス, 193 p.

1966 地団研 (小林英夫編) : 「科学運動」. 築地書館, $322 \mathrm{p}$. われわれの歩み，われわれの科学運動の方針，科学運動の方法，資料，年表を含む.

1966 今井功：明治時代に扮ける始原界諭争一とくに原田・小藤両説を中心として一. 地学雑誌, Vol. 75 , No. $4 \cdot 5$, p. 38-46.

1966 今井功：江戸時代の龍骨論争. 地質ニュース, No. 142, p. 34-38.

1967 小林貞一：日本古生物学界30年を省みて. 化石, No. 13, p. 1-16.

1967 長浜春夫 : 堆積構造からみた古流系の研究史. 5 学会連合学術大会討論会資料「堆積学に関す る諸問題」, p. 159-163.

1967 新井重三 : 我が国にお㳡る堆積構造の研究と今後の課題. 同上, p. 164-168.

1967 藤岡一男 : 秋田油田における 地質学的探鉱の史的展望.「佐々保雄教授還暦記念論文集」, p. 565-581.

1967 小林巌雄 他: 古生物学における近代化の歩み一研究者・学生・教師の立場から一. 地球科学, Vol. 21, No. 4, p. 22-25.

1968 鉄道技術研究所地質研究室 : 鉄道における土木地質学の発展.

1968 「日本の地質学一現状と将来への展望」. 日本地質学会, $610 \mathrm{p}$. 特別寄稿 (渡辺・矢部・坪井), 日本の地質学の展望 (各分野の現状と展望), 日本地質学界の 展望（学会史年表, 会員数と歴代役員, 大学地学教室の現状, 研究所・学協会・関係会社・博 物館の現状など).

1968 坪井誠太郎 : 岩石学雑想一その歩みのあとを回顧して一. 日本地質学会「日本の地質学」, p. $23-32$.

1968 勘米良亀齢・中沢圭二：日本の中古生界の研究の歴史と現状ならびに地向斜に 関する二・三の 
問題. 同上, p. 33-57.

1968 絈野義夫：日本における第三紀層序地質学分野の歴史と現状. 同上, p. 59-75.

1968 小林国夫：日本における第四紀研究. 同上, p. 77-97.

1968 庄司力偉・田口一雄・飯島東：堆積学の現状と将来への展望. 同上, p. 99-122.

1968 山下昇・藤田至則・垣見俊弘 : 日本の構造地質学研究. 同上, p. 124-146.

1968 勝井義雄：日本の火山および火山岩の研究. 同上, p. 147-172.

1968 黒田吉益・青木斌 : 日本の深成岩問題の現状。同上, p. 173-195.

1968 諏訪兼位・端山好和・原郁夫 : 変成岩研究の現状と展望。同上, p. 197-233.

1968 森本信男・久米昭一・渋谷五郎：日本における鉱物学の現状と将来. 同上, p. 235-255.

1968 高柳洋吉：日本の古生物学の現状と展望一とくに有孔虫を中心にして一，同上，p. 257-267.

1968 亀井節夫 : 脊椎動物古生物学の現状と展望. 同上, p. 269-273.

1968 棚井敏雅 : 日本の古植物学研究の発展と今後の課題. 同上, p. 275-286.

1968 徳永重元 : 古花粉学一現在と将来一. 同上, p. 287-291.

1968 本庄丕 : 超微古生物学研究の現状と将来. 同上, p. 294-305.

1968 佐藤任弘・茂木昭夫 : 海底の科学. 同上, p. 307-326.

1968 生沼郁・倉林三郎・加藤芳朗 : 地質学における粘土科学の進歩. 同上, 327-348.

1968 関根良弘・兼平慶一郎：わが国に㧍ける戦後の鉱床の研究. 同上, p. 349-366.

1968 池辺穣 : 石油地質学の進歩. 同上, p. 367-376.

1968 徳永重元: 石炭地質学の進歩. 同上, p. 377-383.

1968 浜地忠男 : ウラン鉱床研究の現状と問題点。同上, p. 385-391.

1968 青木滋・柴崎達雄 : 日本の応用地質学の現状と課題. 同上, p. 393-408.

1968 今井功：日本地質学会史年表. 同上, p. 449-517.

1968 服部一敏・小林宇一 : 大学地学教室に対するアンケートのまとめ. 同上, p. 538-545.

1968 大森昌衛 : 地学関係の長期計画の現状. 同上, p. 592-605.

1968 佐藤博之・斉藤正雄 : 本道地質調査事業の歩み. 地質ニュース, No. 166, 北海道支所創立 20

周年記念号, p. 3-8.

1968 植村癸巳男 : 釷物調查をかえりみて. 同上, p. 9-10.

1968 北海道地質調查の思、出一昭和初期のメモワール一(座談会). 同上, p. 11-15.

1968 曾我部正敏 他：石炭地質学の進歩，地質ニュース, Vol. 166, p. 52-56.

1968 長尾唅一 : 北海道の油田への期待と可能性. 地質ニュース, Vol. 166, p. 57-60.

1968 瀬谷清 : 北海道に抢ける物理探査の足跡. 地質ニュース, Vol. 166, p. 57-60.

1968 佐藤博之：北海道の地質はどのように解明されているか. 地質ニュース, No. 166, p. 64-67.

1968 北海道地質調查今昔談. 地質調查所北海道支所創立二十周年記念事業実行委員会, $39 \mathrm{p}$.

1968 池辺展生 他: ネオテクトニクス研究史. 第四紀研究, Vol. 7, No. 4, p. 140-150.

1968 佐藤光之助：地質調查事業の動向. 地質学雑誌, Vol. 74, No. 11, p. 554-557.

1968 渡辺武男 : 地質学の現状. 地質学雑誌, Vol. 74, No. 11, p. 558-562.

1968 長浜春夫・広川治・遠田朝子 : 堆積構造からみた古流系の研究史. 地質調查所月報, Vol. 19,

No. 1, p. 1-17.

1969 中村一明 他: 活褶曲 研究史と問題点. 第四紀研究, Vol. 7, No. 4, p. 200-211

1969 瀧本清：金属釷床成因論の展望. 水曜会誌, Vol. 16, No. 10, p. 687-692.

1969 松本達郎 : 矢部長克先生と日本の地質学. 科学, Vol. 39, No. 11, p. 620-622.

1969 久城育夫 : 輝石・マントル・月の岩石の研究へ共に歩んだ 30 年 久野教授と Hess 教授の逝去 
を悼む. 科学, Vol. 39 , No. 12 , p. 675-677.

1969 今井功：地質学史からみた雲根志の位置。木内石亭著「雲根志」復刻版, 築地書館, p. 570582.

1969 大森昌衛 : 日本の地質学の課題と展望. 日本の科学者, Vol. 3, No. 5, p. 8-14.

1969 笹嶋貞雄 : 古地磁気層序論一その生いたちと現状の展望。地質学雑誌, Vol. 75, No. 1，p. $13-25$.

1969 前中一晃 : 第四紀の古地磁気研究一その歴史と現状一. 第四紀研究, Vol. 8, No. 2, p. 51-

59.

1969 松下久道 : 九州炭田の炭層探查時代の地質家，九州炭矿技術連盟会誌，Vol. 22，No. 10, p. 349.

1970 小林貞一・鹿間時夫編 :「日本古生物学の回想」. 日本古生物学会, $59 \mathrm{p}$.

1970 後閑文之助 : 明治前の日本古生物学の変遷.「日本古生物学の回想」, p. 1-8.

1970 矢部長克：日本地質学界の思い出とわが生いたちの記.「日本古生物学の回想」, p. 9-33.

1970 早坂一郎 : 大正時代の日本の古生物学史（覚え書き).「日本古生物学の回想」, p. 34-52.

1970 槇山次郎 : 大正時代の古生物学（主として新生代の覚光書き）「「日本古生物学の回想」, p. 5359.

1970 八木健三 : 本邦における最近40年間の岩石学の進歩と展望. 岩石鉱物鉱床学会誌，Vol. 63,

No. 5 , p. 169-185.

1970 須藤俊男 : 本邦における最近 40 年間の鈜物学の進歩と展望。岩石鉱物鉱床学会誌, Vol. 63,

No. 5 , p. $186-205$.

1970 今井秀喜 : 本邦に扔ける最近40年間の鉣床学の進歩と展望. 岩石釷物釷床学会誌, Vol. 63,

No. 5, p. 206-215.

1970 NANBU, M.: Brief History of Descriptive Mineralogy in Japan. "Introduction to

Japanese Minerals" (Organizing Committee IMA-IAGOD Meetings '70), Geological Surv.

of Japan, p. 1-5.

1970 橋本光男 : 夜久野塩基性岩研究略史. 地質学雑誌, Vol. 76, No. 9, p. 449-454.

1971 小林貞一：国際層位学委員会とその層位分類部会. 地学雑誌, Vol. 80, No. 2, p. 60-61.

1971 小林貞一: INHIGEO と DDR 地学史資料集. 地学雑誌, Vol. 80, No. 2, p. 49-50.

1971 小林貞一 : 矢部長克先生と日本古生物学会. 化石, No. 21, p. 57-61.

1972 桜井欽一：鈗物徒然草(1). 地質ニュース, No. 209, p. 16-21.

1972 河合正虎：地質図幅事業の歴史と展望。地質ニュース, No. 220, p. 2-37.

1972 鈴木尉元 他 5 名 : 地質調查所に㧍ける戦後の石油・天然ガス調查事業と今後の課題. 地質ニ ユース, No. 220, p. 91-101.

1972 今井功 : 年表地質調查所 90 年史. 地質ニュース, No. 220, p. 185-210.

1972 沢村孝之助 : 明治期の伊豆半島地質調查.「伊豆半島」, 東海大学出版会, p. 35-39.

1972 73 牛来正夫：わがカコウ岩研究史を語るー1・2-(ノート). 地球科学, Vol. 26, No. 6,

p. 265-269, Vol. 27, No. 1, p. 44-46.

1973 中山勇: 岩石学研究方法の討論の歴史的経過について. 地球科学, Vol. 27, No. 4, p. 141147.

1973 河合正虎：地質調查所における地質図．地質調查所月報，Vol. 24，No. 11，p. 563-588.

1973 鈴木醇先生記念出版会 :「鈴木醇一人とその背景一」. $325 \mathrm{p}$.

研究業績編, 地質学外史編, 思い出編に分れている. 
1973 原田準平 : 故鈴木醇北大名誉教授が関係された大学，学会および研究機関.「鈴木醇一人とそ の背景一」, p. 49-66.

1973 大森昌衛 : 地球科学の課題一生産との結合に焦点を扔いて一.「現代の科学論 I 」, 頸草書房, p. $95-135$.

1973 原田準平 : わが国の鉱物学の歩み (特別講演)。鉱物学雑誌, Vol. 11, No. 1・2, p. 1-18.

1974 PestanA, H. R. : History of Geology in Japan and Northern Asia: Documents Published by the United States Congress. Japanese Studies in the History of Science, No. 13, p. 69-73.

1974. ImaI, I. : History of Geological Research in Japan. XIVth Intern. Congr. History of Science, Japan, Proc. No. 3, p. 101-104.

1976 立岩嚴 :「朝鮮一日本列島地帯地質構造論考一朝鮮地質調查研究史一」。東京大学出版会, 680

p. 写真・図版 137 .

1976 清水大吉郎：地向斜研究の歴史と現在の課題. 地団研専報, No. 19, p. 1-11.

1976 富阪武士編 : 「造岩鉱物学の進歩」. 日本岩石釷物鉱床学会特別号, 第 1 号, 日本岩石鉱物鉱床 学会, $352 \mathrm{p}$.

1976 坪井誠太郎 : 造岩鉱物研究余談。「造岩鉱物学の進歩」, p. 3-5.

1976 渡辺武男: 火山岩に伴うゼノリス (Xenolith, enclaves, inclusions and nodules) の研究に ついて.「造岩鉱物学の進歩」, p. 7-25.

1976 秋月瑞彦: 水長石一その研究史と問題点.「造岩釷物学の進歩」. p. 105-118.

1976 Matsumoto, T. et. al. ed: "A Concise History of Palaeontology in Japan". Trans. Proc. Palaeontol. Soc. Japan, NS, No. 100, Supplement, 80 p.

Introduction (Kobayashi, T.), Paleontology and Society of Japan (Ujiie, H.), Paleozoie Microfossils(Igo, H.), Post-Paleozoic Micropaleontology (Takayanagi, Y.), Coelenterates (Kato, M.), Bryozoa (Sakagami, S.), Brachiopoda(Yanagida, J.), Cephalopoda (Obata, I.), Mollusca(Shuto T.), Arthropoda(Hamada, T.), Echinodermata(Morishita, A.), Vertebrata (Kamei, T.), Problematica \& Trace Fossils (Noda, H.), Paleozoic Plants (Asama, K.), Mesozoic Plants(Kimura, T.) Cenozoic Plants(Tanai, T.), Paleopalynology (Tokunaga, S.), Algal Conservatism(Konishi, K.), Concluding Remarks (Matsumoto T.).

\section{II. 地理・測地・地図}

1880 河田熊：日本地誌源委を論ず。東京地学協会報告, 2 年, Vol. 3, p. 1-22.

1882 荒井郁之助 : 測量術沿革考. 東京地学協会報告, 4 年, No. 5, p. 1-23.

1883 二見鏡三郎 : 本邦三角測量の実況。東京地学協会報告, 4 年, No. 9, p. 1-18.

1884 二見鏡三郎：量地学一班附本邦三角測量ノ実況。学芸志林, Vol. 13, No. 72, p. 76-99.

1889 大川通久：日本古今測地一班。東京地学協会報告，1集，No. 4.

1922 「陸地測量部沿革誌」. 陸地測量部, $319 \mathrm{p}$.

1930 高木菊三郎：我国に於ける地形図製作の略史。地球，Vol. 14，No. 2, p. 27-36.

1930 芦田伊人：「日本総図の沿革」. 国史回顧会紀要, 第 2 冊.

1931 藤田元春 :「日本地理学史」. 刀江書院，683 p. 図版 6 枚. (1942年改訂増補版. 667 p.)

1931 高木菊三郎 :「日本地図測量小史」. 古今書院, $197 \mathrm{p}$.

1931 藤田元春:「江戸時代に於ける我国地理学の発達」. 岩波講座, 地理学(別項), 23 p. 
1932 岩根保重 :「徳川時代地誌の概観」. 岩波講座, 地理学(別項).

1932 栗田元次:「日本古版地図集成」. 博多成象堂, 大版90葉, 解説, $132 \mathrm{p}$.

1934 村松繁樹 :「日本地理学史」. 岩波講座, 地理学 (総論), $96 \mathrm{p}$.

1934 芦田伊人:「日本地図の発達」。岩波講座, 日本歷史, $30 \mathrm{p}$.

1935 秋岡武次郎：「欧人の初期日本地図作成史」。岩波講座，日本歷史， $44 \mathrm{p}$.

1935 36 岡山俊雄: 本邦水河問題の回顧と現状 (上), (中). 山岳, No. 30, p. 195-216. No. 31, p. $365-401$.

1940 飯本信之 :「地理学発達史」. 中興館, 258 p. +10 p.

1940 石田竜次郎：皇国地誌編纂始末 日本地理学史の一頁. 地学雑誌, Vol. 52, No. 614，p. 140149 .

1943 鮎沢信太郎 : 「大日本海一日本地理学史の研究一」. 京成社出版部, 327 p. 図版 5 枚.

1943 鮎沢信太郎：「鎖国時代の世界地理学」. 日大堂, 363 p. 図版10枚.

1943 山口貞雄 :「日本を中心とする輓近地理学発達史」. 済美堂, 265 p.

1943 高木菊三郎 :「地形図学概論」. 山一書房, $417 \mathrm{p}$.

1947 三上美夫：「日本地形測量史之研究」。 恒星社厚生閣.

1948 鮎沢信太郎：「地理学史の研究」. 愛日書院, 429 p.

1948 鮎沢信太郎：「近世日本の世界地理学」。東光協会出版社，文化選書 7, 66 p.

1951 高木菊三郎：旧内務省地理局出版に係る地理関係の図書と地図の目録。地理調查所時報，第 2 集, p. 10.

1952 秋岡武次郎 : 伊能忠敬作の日本全図の種類.「内田寞一先生還暦記念地理学論文集」, 上巻, 帝 国書院。

1953 開国百年記念文化事業会編 :「鎖国時代日本人の 海外知識一世界地理 西洋史に関する 文献解 題」. 乾元社, $498 \mathrm{p}$.

1954 江原真伍 : 東亜大陸と三人の地理学者一本邦に於る地理学進展の一時期一. 立命館文学, No. 105, p. 124-130.

1954 渡辺光 : 明治初年以来の地理学の歩み. 地学雑誌，Vol. 63，No. 3, p. 72-78.

1954 宮部直巳：測地学75年. 地学雑誌, Vol. 63, No. 3, p. 18-22.

1954 片山平三：測量器械類製造業者の変遷. 測量, Vol. 4, No. 11, p. 23-27.

1955 秋岡武次郎：「日本地図史」. 河出書房, $217 \mathrm{p}$. 地図38枚.

1956 「日本地理学会史編年資料草稿 (1925-55)」. 日本地理学会, $65 \mathrm{p}$.

1956 辻村太郎：日本地形学の足跡. 地理, No. 3, p. 99-108.

1956 久松将四郎：地質調查のための測量の歴史（その 1 ), （その 2 ）。地学雑誌，Vol. 65, No. 2, p. 89-99. No. 3, p. 131-139.

1956 石山洋: 明治地文学と Sir Archibald Geikie.「过村太郎先生古稀記念地理学論文集」, 古今書 院, p. 612-621.

1957 大村斉：本邦測量事業の回顧。地学雑誌, Vol. 66, No. 1, p. 42-50.

1957 藤井陽一郎：明治初年に扔ける北海道の三角測量について. 科学史研究, No. 45, p. 9-14.

1958 辻村太郎：日本地形学の足跡.「日本の山水」, 宝文館, p. 180-194.

1959 藤井陽一郎 : 沼津兵学校とその日本近代測量事業への影響について. 科学史研究, No. $51, p$. $1-7$.

1960 渡辺光：日本地理学の戦後の動向. 地学雑誌, Vol. 69, No. 4, p. 145-152.

1960 藤井陽一郎：工部省測量司による東京府下測量について. 科学史研究, No. 54, p. 20-25. 
1961 中村拓：「鎖国前における南蛮人の作れる日本地図」. 東洋文庫, 2 冊, $427 \mathrm{p}$. 別冊, 図 104

枚.

1962 木村東一郎 :「近世村絵図研究」. 小宮山書店, $256 \mathrm{p}$.

1962 村田近良 : 測量80年の歩み.「地質調查所略史」, p. 39-46.

1963 大森八四郎：地形図図式の変遷。地図, Vol. 1, No. 1-2.

1964 藤井陽一郎 : 内務省地理局の三角測量事業. 科学史研究, No. 70, p. 72-83.

1964 大森八四郎 : 地形図図式変遷表. 地図, Vol. 2, No. 2, 別刷.

1964 65 清水靖夫 : 初期の地形図類. 地図, Vol. 2, No. 1, No. 3. Vol. 3, No. 2.

1964 日本の土木技術編集委員会編 :「日本の土木技術一100年の歩み一」（土木学会創立 50 周年記念 出版). 土木学会, $477 \mathrm{p}$.

1965 石田龍次郎：日本の地理学その発達と性格についての小論。地理, Vol. 10, No. 1, p. 27-49.

1965 最近に扔ける地理学の動向一その発展と課題一. 地理, Vol. 10, No. 1, p. 50-64.

1965 清水靖夫·大森八四郎 : 五千分一東京図. 地図, Vol. 3, No. 1, p. 1-6.

1965 土木学会:「日本土木史」一測量編一(大正元年一昭和 15 年).

1965 清水靖夫 : 明治期の地図. ビブリア, Vol. 32, No. 10, p. 139-148.

1965 細山謙之輔：測地観測所の今昔. 国土地理院時報, Vol. 30, No. 10, p. 42.

1966 石田龍次郎：日本に打ける地誌の伝統とその思想的背景. 地理学評論, Vol. 39, No. 6, p. $348-356$.

1966 坪井忠二 : 武藤勝彦博士の研究業績と当時の背景. 測地学会誌, Vol. 12, No. 1, p. 1-11.

1966 藤井陽一郎 : 伊能忠敬の測地法. 測量, Vol. 16, No. 4, p. 28-33. No. 6, p. 22-26.

1966 中野尊正：日本の地図学100年の歩み. 地図, Vol. 4, No. 2, p. 49-54.

1966 地図年表（維新前一昭和40年）。国土地理院時報, Vol. 31, p. 41-61.

1966 藤井陽一郎：日本の測地学の歴史的特質 “測地学長期計画に関連して”. 科学, Vol. 36, No.

6 , p. $323-327$.

1966 高木菊三郎：「日本に於ける地図測量の発達に関する研究」. 風間書房, $175 \mathrm{p}$.

1967 中野尊正 : 日本地形学の歩み.「日本の地形」, 築地書館, p. 1-43.

1967 岡山俊雄 : 本邦水河問題研究拾遺. 駿台史学, Vol. 21, p. 100-116.

1967 片山三平: 測量機械の発達史. 測量, Vol. 17, No. 3-5.

1967 中野尊正 : 地代地困学の確立. 朝倉地理学講座 3 「地図学」, p. 38-54.

1967 中野尊正：日本の地図の近代化 (明治以後). 朝倉地理学講座 3 「地図学」, p. 54-66.

1967 高木菊三郎：日本に㧍ける初期の地図測量. 地理, Vol. 12, No. 4, p. 7-13.

1967 東北地理学会小史1947 1967. 東北地理, Vol. 19, No. 4, p. 1-6.

1968 多田文男 : 鳥取砂丘生成に関する研究史, 地理, Vol. 13, No. 7, p. 7-13.

1968 保柳睦美: 伊能図の意義と特色. 地学雑誌, Vol. 77, No. 4, p. 1-30.

1968 氷河学懇話会 : 水河調査小史. 雪水, Vol. 30, No. 4, p. 115-123.

1969 保柳睦美: 東京地学協会と伊能忠敬. 地学雑誌, Vol. 78, No. 3, p. 42-52.

1969 石田龍次郎：「東京地学協会報告」(明治12 30年)一明治前半の日本地理学史資料として。一 橋大学研究年報 (社会学研究), Vol. 10, p. 1-83.

1969 岡山俊雄 : W. ウエストン「日本水河遺跡論」と明治十年代前半の水河不存在論その他. 山岳,

Vol. 63, No. 7, p. 1-31.

1969 国松久弥: 経済地理学の回顧と展望. 茨城大学政経学会雑誌, Vol. 24, p. 1-40.

1969 日本国際地図学会: 明治以降本邦地図目録. $181 \mathrm{p}$. 
1969 日本国際地図学会地図史専門部会 : 地形図類図歴表一1. 地図, Vol. 7, No. 4,

1969 南波松太郎・室賀信夫・海野一隆編：「日本の古地図」，創元社（大阪），大版，192 p.

1969 番匠勲：開拓使による北海道の三角測量. 測量, Vol. 19, No. 5, p. 24-27.

1969 本田弘人：わが国における測地その他の地球物理学的事業の沿革。学術月報, Vol. 22, No.

1, p. 24-26.

1969 大久保武彦：日本に抢ける地図体系の発展。早稲田大学学術研究, 自然科学, 18, p. 23-36.

1969 山中光一: 測地学委員会の活動。学術月報, Vol. 22, No. 1, p. 2-8.

1969 山中光一：測地学審議会の 20 年. 学術月報, Vol. 22, No. 1, p. 8-23.

1969 藤井陽一郎：測地学者としての長岡半太郎. 物理学史研究, Vol. 5, No. 1, p. 1-27.

1970 辻村太郎：東西両京の地理学者 山崎直方と小川环治. 地理, Vol. 15, No. 12, p. 7-14.

1970 石田竜次郎：山崎直方と小川玩治 東西両大学の地理学講座創設まで. 地理, Vol. 15, No.

12 (山崎・ 小川両先生を偲ぶ), p. 21-27.

1970 渡辺光：山崎直方教授と日本の現代地理学. 地理, Vol. 15, No. 12, p. 28-33.

1970 米倉二郎: 小川先生と地理学. 地理, Vol. 15, No. 12, p. 34-40.

1970 国土地理院監修:「測量・地図百年史」. 日本測量協会, $672 \mathrm{p}$.

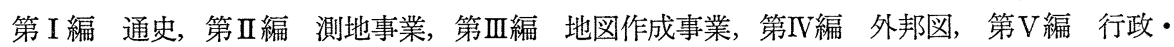
研究・関連事業, および年表・資料.

1970 岩田豊樹：江戸地図の図歷. 地図, Vol. 8, No. 2, p. 11-16.

1970 関口正雄 : 明治 8 年測量「習志野及周囲邨落図」をめぐつて（日本陸軍の歩みを基礎にした地

図発達史の解明一1一)。地図, Vol. 8, No. 3, p. 1-3.

1970 日本国際地図学会地図史専門部会: 地形図類図歴表一 2-. 地図, Vol. 8, No. 1, p. 31-43.

1970 建設省国土地理院測量 - 地図百年史編集委員会 : 国土地理院年表。国土地理院時報, No. 39,

p. 1-39.

1971 辻田右左男 :「日本近世の地理学」. 柳原畫店, $337 \mathrm{p}$.

1971 石田龍次郎 :「地学雑誌」創刊（明治22年）上り関東大地震まで（日本の近代地理学の 系譜研

究. 資料-3-). 一橋大学研究年報 (社会学研究), 11, p. 1-95.

1971 石田龍次郎 : 明治・大正期の日本地理学界の思想的動向 山崎直方・小川环治の 昭和期への役

割. 地理学評論, Vol. 44, No. 8, p. 532-558.

1971 秋岡武次郎 : 「日本地図作成史」. 鹿島研究所出版会, 地図 109 枚, 別巻 $156 \mathrm{p}$.

1971 尾崎幸男 : 写真測量の摇藍期 (測量 - 地図百年史外伝)。測量, Vol. 21, No. 6, p. 9-11.

1971 藤井陽一郎：測地学委員会と日本の測地学. 日本天文研究会報文, Vol. 4, No. 4, p. 217-220.

1971 佐々保雄 : 北海道地図・測量こぼれ話（北海道特集）。測量, Vol. 21, No. 9, p. 18-24.

1971 平野吉之助：えぞ地図から北海道地図に至る技術の小史 (北海道特集). 測量, Vol. 21, No.

9, p. 39-43.

1971 矢沢大二: 東京都立大学理学部地理学教室史稿. $39 \mathrm{p}$.

1972 大島太市：日本写真測量学会10年のあゆみ.写真測量, Vol. 10 (写真測量の 10 周年記念特集号), p. $15-76$.

1972 柳辰平 : 戦後の民間写真測量業界の歩み. 写真測量, Vol. 10, p. 97-101.

1972 日本写真測量発達史年表. 写真測量, Vol. 10, p. 102-152.

1972 日本国際地図学会: Cartography in Japan.

1972 菊地政夫：わが国の地図作成と図式の変遷。軍事史学, Vol. 7, No. 4, p. 27-34.

1972 海野一隆・織田武雄・室賀信夫編：「日本古地図大成」。講談社，p. 211-289. 
1973 東京大学総合研究資料館 :「日本に扔ける地図の歩み」(昭和 48 年 9 月 1 日一昭和 49 年 4 月 30 日 第 9 回展示). 8 p.

1973 吉川虎雄 他: 日本の地形学の歩みと課題.「新編日本地形論」, 東京大学出版会, p. 372-392.

1973 織田武雄 : 日本の地罒とその発達.「地図の歴史」, 講談社, p. 211-289.

1973 渡辺光 : この10年間の地図学の歩み. 地図, Vol. 11, No. 1, p. 1-10.

1973 岡本良知:「十六世紀に打ける日本地図の発達」. 八木書店, $306 \mathrm{p}$.

1973 五条英司：日本の地形図 歴史的変遷（読図と解説特集）。地理，Vol. 18, No. 10, p. 40-48.

1974 岡山俊雄 : 明治大学文学部地理学教室の歩み 文科専門部史学科・地理歴史科時代. 駿台史学, No. 36 , p. $68-80$.

1974 松井貞雄 : 地理学教室の歴史 (愛知教育大学). 地理学報告, No. $41 \cdot 42$, p. 55-60.

1974 岡山俊雄 :「日本の山地地形と氷河問題研究小史」. 古今書院, $246 \mathrm{p}$.

1974 石山洋: 展望地理学史. 科学史研究, Vol. 13, No. 110, p. 49-55.

1974 多田文男: 平野研究におけるあけぼの。地理 (日本の地理学史特集), Vol. 19, No. 5, p. 1129.

1974 織田武雄 :「地球学団」と「地球」. 地理（日本の地理学史特集）, Vol. 19, No. 5, p. 20-22. 1974 辻田右左男 : 人文地理学の芽が萌えだしたころ. 地理（日本の地理学史特集）, Vol. 19, No.

5, p. 23-29.

1974 奥野中彦: 古代図と図師。 日本歴史, No. 311, p. 78-89.

1974 織田武雄 :「地図の歴史一日本篇一」. 講談社現代新書, $188 \mathrm{p}$.

1974 保柳睦美編著 :「伊能忠敬の科学的業績」. 古今書院, $510 \mathrm{p}$.

1974 矢守一彦:「都市図の歴史一日本編一」. 講談社, $478 \mathrm{p}$.

1974 中村作太郎：科学の発達と測量学の歷史的変遷. 測量, Vol. 24, No. 3, p. 29-33.

1974 竹内啓一：日本におけるゲオポリティクと地理学. 一橋論叢, Vol. 72, No. 2, p. 13-35.

1974 FUJII, Y: : Early History of Modern Geodetic Works in Japan. XIV Intern. Congr.

History of Science, Japan. Proc. No. 3, p. 85-87.

1974 75 佐藤侻: 地形図の歴史一 1, 3-. 地理, Vol. 19, No. 8, p. 129-135. No. 12, p. 51-

58. Vol. 20, No. 9, p. 129-136.

1975 日本地理学会編 :「日本地理学会五十年史」. 255 p. 付表 1 .

1975 岡山俊雄 : 氷河地形研究史概報. 地理学評論, Vol. 48, No. 3, p. 151-153.

1975 多田文男 : 日本地理学界50年の歩み. 地理学評論, Vol. 48, No. 9, p. 609-615.

1975 織田武雄：アトラス（地図帖）の歴史. 地理学評論, Vol. 48, No. 9, p. 639-644.

1975 渡辺光 : 地理学文献解説一昭和18年まで一自然地理部門. 地理, Vol. 20, No. 5, p. 7-15.

1975 石山洋：日本の地理教科書の変遷一幕末・明治前期をめぐって一. 地理, Vol. 20, No. 5, p. 16-21.

1976 水岡不二雄 : 日本文化加々た地理学発達の歷史. 日本の科学者, Vol. 11, No. 10, p. 1316.

\section{III. 地震 ·火山・地球物理}

1880 Milne, J.: Seismic Science in Japan. Trans. Seism. Vol, 1, pt. 1, p. 3-34.

1882 Milne, J. : Seismology in Japan. Nature, Vol. 26, p. 627-631.

1884 和田雄治 : 本邦地震考. 統計集誌, Vol. 30, p. 48-50.

1884 MiLne, J. : Catalogue of the Seismological Society's Publications, together with other 
recent publications chiefly referring to seismic and volcanic phenomena in Japan. Trans.

Seism. Vol. 7, pt. 2, p. 89-92.

1886 関谷清景 : 地震書籍. 東洋学芸雑誌, Vol. 3, No. 60, p. 712-714. No. 61, p. 30-31.

1886 Ewing, J. A. : Seismology in Japan. Nature, Vol. 34, p. 195-196.

1887 Milne, J. : Important Points in the History of Earthquake Investigation in Japan. Nature, Vol. 35, p. 559-560.

1904 菊地大麓 : Recent Seismological Investigations in Japan. Publ. Earthq. Inv. Comm. in

Foreign Languages, No. 19.

1926 IMAMURA, A.: The Great Earthquake of S. E. Japan in Sept. 1, 1923 with two Appendices. Third Pan-Pacific Science Congress, Tokyo., "Scientific Japan, Past and Present", p. 141-176, pls. 13-46, 1 map.

1926 Terada, T. and Matsuzawa, T.: A Historical Sketch of the Development of Seismology in Japan. Third Pan-Pacific Science Congress, Tokyo., "Scientific Japan, Past and Present", p. 251-310.

1927 Davison, C.: The Fouunders of Seismology.

1928 寺田寅彦・松沢武雄著, 坪井忠二訳補：「我が国に於ける地震学の発達」. 岩波書店.

1929 今村明恒 : 明治大正間に於ける本邦地震学の発達. 地震, Vol. 1, No. 2, p. 10-41.

1931 石本巳四雄：日本古来の地震原因観．地震，Vol. 3， No. 1， p. 39-44.

1935 「東京大学地震研究所一覧」.

1937 石本巳四雄 : 徳川時代に於ける地震学. 地震, Vol. 9, No. 3 8.

1937 石本巳四雄 : 明治大正時代における地震学. 地理学, Vol. 5, No. 7〜9.

1942 石本巳四雄 : 地震学よりみたる日本の文化. 文部省教学局.

1948 物理探釷編集委員会 : 本邦に於ける物理探鉱の回顧と展望. 物理探鉱, Vol. 1, No. 1, p. 29.

1949 飯田汲事 : 最近における物理探鉣の動向. 地学雑誌, Vo. 58, No. 4-5. p. 34-38.

1950 萩原尊礼：地震研究所創立25周年を迎えて. 科学, Vol. 20, p. 503-510.

1951 「地震学・地球電磁気学・火山物理学の概観」. 日本学術振興会, $112 \mathrm{p}$.

1951 中央気象台地震課：地震観測業務の沿革と現状. 測候時報, Vol. 18, p. 251-253.

1953 東京大学地震研究所 : 「東京大学地震研究所浅間火山観測所 1933-1953」. 6 p.

1954 松沢武雄 : 日本の地震学の歩み. 地学雑誌, Vol. 63, No. 3, p. 23-28.

1954 津屋弘達 : 日本の火山研究の回顧. 地学雑誌, Vol. 63, No. 3, p. 29-34.

1958 物理探鉱十周年特別号. 物理探鉱, Vol. 11, No. 4, 414 p.

基礎技術編として地震・重力・電気・磁気・放射能・地温の各探鉱の 6 章にわかれ，それぞれ に歴史の項がある。また応用編として，石油・石炭・鉣山の探鈗および土木・地下水・地熱温 泉の探査の 6 章がある.

1961 佐藤光之助 : 物理探查の最近の進歩について. 鉱山地質, Vol. 11, No. 45-46, p. 365-369.

1964 今村明恒・岸上冬彦 : 地震学. 日本学士院編「明治前日本物理化学史」第四章.

1965 諏訪彰 : 気象庁による火山観測の沿革と現状. 火山, No. 10, p. 133-138.

1965 久野久：日本火山学会 10 年の歩みと将来の目標。火山, 第 2 集, No. 10 (10周年特集号), p. $1-6$.

1965 坪井忠二 : 大森房吉と日本の地震学. 中央公論, Vol. 80, No. 7. p. 383-388.

1966 藤井陽一郎 : 地震学者今村明恒の震災論。科学史研究, No. 80, p. 161-170. 
1966 橋本万平: 関谷清景と日本の地震学-1-. 科学史研究, No. 77, p. 1-9.

1966 笠原慶一：地震学が生れるまで. 「地震の科学」, 恒星社, p. 9-13.

1966 服部保正 : 土木地質調查に利用される物理探査の変遷と展望. 土木技術, Vol. 21，No. 9.

1967 宮村摂三 他：日本の地震学の現状と課題. 日本の科学者, Vol. 1, No. 6, p. 2-8.

1967 藤并陽一郎 : 「日本の地震学」。紀伊国屋新書, $239 \mathrm{p}$.

1967 宇佐美竜夫・浜松音蔵：日本の地震抢よび地震学の歴史。日本の地震学の概観, 第一編, 地震, 第 2 輯, Vol. 20, No. 4, p. 1-34.

1967 玉城逸夫：日本の地震学研究と科学のあり方. 日本の科学者, Vol. 2, No. 1, p. 18-20.

1968 渡辺貫 : 物理探查の進展. 地質工学, 5 輯. p. 1-4.

1968 「最近に抢ける物理探鉱の進歩」. 物理探鉣技術協会, $242 \mathrm{p}$.

第 1 章 本邦物理探査の最近 10 年の歩夕と将来の展望. 第 2 章 新しい物理探査.

1968 藤井陽一郎: 石本巳四雄に拈ける地震研究と科学史 - 科学論 1.2. 科学史研究, 2 期, Vol. 7 ,

No. 85 , p. 22-31. Vol. 8, No. 91 , p. 146-154.

1969 高原栄二:田中館愛橘の地磁気研究活動. 物理学史研究, Vol. 5, No. 4, p. 37-50.

1969 寺本晃: 田中館愛橘と明治初期の重力測定. 物理学史研究, Vol. 5, No. 4, p. 27-36.

1969 武居由之: 電気検層の沿革. 地質ニュース, No. 181, p. 16-21.

1969 前中一晃: 第四紀の古地磁気研究 その歴史と現状. 第四紀研究, Vol. 8, No. 2, p. 51-59.

1970 諏訪彰：日本の火山観測事業の発展. 上, 下. 地理, Vol. 15, No. 5, p. 66-71. No. 6, p. 70-75.

1970 小野吉彦：地質調查所物理探査部の発展と現状，測量，Vol. 20, No. 2, p. 21-25.

1971 小林和男 : 海洋底地球物理学. 日本海洋学会誌, Vol. 27, No. 6, p. 301-311.

1971 野越三雄 : 微動研究の歷史的変遷. 地震探鉣実験グループ会報, No. 56, p. 14-31.

1971 上田誠也：地球物理学一 60 年代から 70 年代一一。自然, No. 9, 43-49.

1972 空中磁気探査研究会のあ杪夕. 物理探鉱, Vol. 24, No. 6, p. 340-341.

1972 陶山淳治 : 物理探査の発展と今後の動向. 地質ニュース, No. 220, p. 110-119.

1972 服部保正：日本物理探鉱株式会社における弾性波探查30年の歷史. 地質工学, 8輯, p. 118142.

1972 表俊一郎 : 地震工学発展の歩み (第 2 部). 地質工学, 8 輯, p. 18-44.

1974 永田武: 地球磁気学100年の歩み. 自然, No. 8, p. 28-46.

1975 「地震研究所創立五十年の歩み」. 東京大学地震研究所, $140 \mathrm{p}$.

1976 鈴木尉元 : 関東地方の地震研究の問題点と地質学的課題. 地質ニュース, No. 257, p. 24-34.

1976 杉村新 : 「断層と地震」その歴史と展望. 地質学論集, No. 12, p. 3-13.

1976 村松郁栄: 根尾谷断層と濃尾地震. 地質学論集, No. 12, p. 117-127.

\section{IV. 気 象}

1888 荒井郁之助：本邦測候沿革史. 気像集誌, Vol. 7, No. 1.

1900 「中央気象台一覧」.

1903 「中央気象台一覧」.

1911 「中央気象台一覧」.

1924 中村精男: 「中央気象台沿革概要」.

1926 「中央気象台一覧」。 
1926 OKADA, T.: The Climate of Japan with a Note on the Meteorological Service in Japan. Third Pan-Pacific Science Congress, Tokyo., "Scientific Japan, Past and Present",, p. 33-53.

1932 「中央気象台一覧」.

1933 岡田武松 :「測候珼談」. 鉄塔書院, $448 \mathrm{p}$.

1937 佐藤順一・山田㻟雄 : 気象観測法の沿革. 測候時報, Vol. 8. No. 24.

1937 「中央気象台一覧」.

1939 岡田武松 :「続測候頊談」. 岩波書店, 293 p.

1941 荒川秀俊 : 「日本気象学史」. 河出書房科学新書, $191 \mathrm{p}$.

1941 田口龍雄 : 「風祭」. 古今書院, $233 \mathrm{p}$.

1941 田口龍雄 :「続風祭」. 古今書院, $191 \mathrm{p}$.

1948 高橋浩一郎：戦争中に打稀気予報の進歩. 科学, Vol. 17, No. 2, p. 40-44.

1948 荒川秀俊 :「気象学発達史」(再版). 河出書房, $174 \mathrm{p}$.

1948 日本雪水学会編 : 「最近雪水学の概観一雪水十年」. 東海書房, $240 \mathrm{p}$.

1949 岡田武松:「気像学の開拓者」. 岩波書店, $312 \mathrm{p}$.

1950 藤原咲平:「群渦一気象四十年」. 羽田書店, $293 \mathrm{p}$.

1950 高層気象台：高層気象台創立30年の回顧と現状. 高層気象台彙報特別号, p. 1-85.

1951 藤原咲平:「日本気象学史」. 岩波書店, $177 \mathrm{p}$.

1952 岡田武松 : 本邦天気予報事業の今昔. 測候時報, Vol. 19, No. 14 .

1952 中央気象台研修所創立30周年記念特集。研修時報.

1953 測候所，気象台創設事情特輯号. 測候時報, Vol. 20, No. 11.

1953 渡辺和夫 : 印刷天気図の変遷. 測候時報, Vol. 20, No. 15 .

1954 和達清夫・荒川秀俊: わが国の気象学・気象事業史. 地学雑誌, Vol. 63, No. 3, p. 13-17.

1954 堀内剛二 : 本邦気象事業創設史考 I VIII. 測候時報, Vol. 21, No. 1-8.

1954 堀内剛二: 本邦暴風警報創業始末 $\mathrm{I} \sim \mathrm{X}$. 測候時報, Vol. 21, No. 9 .

1955 大谷東平: 「天気予報三十年」. 法政大学出版局, $250 \mathrm{p}$.

1955 気象学史特集号. 天気, Vol. 2, No. 7.

1955 座談会ラジオゾンデの歴史．高層気象, Vol. 2, No. 1.

1956 気象学史研究会編 :「日本の気象一気象史の一断面一」. 三一書房, $212 \mathrm{p}$.

1956 根本順吉 : 日本の気象の諸断面. 自然, Vol. 11, No. 11, p. 42-50.

1957 日本気象学会編：「日本気象学会75年史」. $68 \mathrm{p}$.

1958 武田武: 気象研究所の生い立ち. 気象研だより, No. 1.

1959 「電力気象三十年誌」. 電力気象連絡会.

1959 荒川秀俊 :「日本と世界の気象」. 東都書房.

1960 「気像協会10年の歩み」. 気像協会.

1960 気象災害研究会編：「日本の台風災害」，東洋経済新報社．

1960 鯉沼寛一：防災気象事業の展望. 測候時報, Vol. 27, No. 5.

1960 農林省林業試験場編 :「第一期治水事業の森林測候所」. 林野共済会.

1964 海と空沿革史. 海と空, Vol. 40, No. 1.

1965 久保次郎：工業気象の歴史的展望. 気象研究ノート, Vol. 15, No. 4, p. 623-631.

1965 高橋浩一郎: 気象学研究の歴史的展望. 天気, Vol. 12, No. 1, p. 12-14.

1966 鯉沼寬一：北海道開拓と気象観測。気象, No. 115, p. 1705. 
1966 鯉沼寛一：ばらばらにはじまつた政府の気象観測。気象，No. 116, p. 1732-1733.

1966 川崎英男: 台風発生地南洋群島の気象測候史. 測候時報, Vol. 33, No. 1・2, p. 1-75.

1967 「群馬県気象災害史」。前橋地方気象台, $188 \mathrm{p}$.

1968 鯉沼宽一：初期の日本気像業務史 1.2 測候時報, Vol. 35, No. 4, p. 127-133, No. 6, p. $218-224$.

1968 鯉沼寛一：日本の気象観測の始まり. 天気, Vol. 15, No. 1, p. 29-31.

1968 樋口敬二：日本に打汀雪溪の水河学的研究. 雪水, Vol. 30, No. 6, p. 195-207. 1968 69 鯉沼寛一 : 初期の日本気象業務史. $3 \sim 6$. 測候時報, Vol. 35, No. 7, p. 264-269.

No. 8 , p. 300-306. No. 9 , p. 330-338. No. 11, p. 419-424.

1969 鯉沼寛一：内務省における気象観測の開始の経緯と気象台の名称. 天気, Vol. 16, No. 3, p. 105-108.

1969 関口武：日本における気候学の進歩。「現代気候学論説」, 東京堂.

1969 日本科学者会議大阪支部気象台分会：支気象学者の伝記から見た気象史. 日本の科学者,

Vol. 3, No. 5, p. 21-24.

1969 堀内剛二: 気象学百年偶感. 気象学研究ノート, Vol. 10, p. 498-500.

1969 回顧と抱負 戦後 20 年の時点に立つて (特集)。気象研究ノート, 100, p. 151-402.

1971 福井英一郎：気候学50年の歩夕. 天気, Vol. 18, No. 8, p. 386-394.

1971 27 函館海洋気象台：函館海洋気象台沿革誌 1872-1972. 1，2. 測候時報, Vol. 38, No. 12, p. 406-454. Vol. 39 , No. 1 , p. 22-49.

1972 福井英一郎：気候学とともに四十年. 地理, Vol. 17, No. 1, p. 143-152. Vol. 17, No. 2, p. $80-84$.

1972 東京教育大学気候学研究室: Japanese Progress in Climatology. 110 p.

1973 具志幸孝: 琉球の気象史. 測候時報, Vol. 39, No. 12, p. 473-494.

1974 Nemoto, J.: Some Characteristics of the History of Meteorology in Japan. Japanese

Studies in the History of Science, No. 13, p. 1-8.

1975 特集気象百年. 気象, No. 6.

1975 気像庁：「気象百年史」. 日本気象学会, $740 \mathrm{p}$. 同「資料編」. $442 \mathrm{p}$.

1975 特集日本の気象一気象百年にあたつて一、科学の実験, No. 6, 17-67.

\section{V. 陸水・地球化学}

1939 柴田雄次 : 本邦に於ける地球化学の現況。科学知識, Vol. 19, No. 4, p. 46-49.

1939 野満隆治：日本に扔ける河川等。日本宇宙及び地球物理学輯報。

1939 田中阿歌麿：湖沼とともに四十年. 科学知識, Vol. 19, No. 8, p. 30-41.

1940 田中阿歌麿：「湖」。岡倉書房.

1943 吉村信吉 : 論文を通して見た日本湖沼学発達史. 科学, Vol. 13，p. 212-213.

1946 菅原健：地球化学論。科学知識, Vol. 26, No. 10-12.

1951 蔵田延男：日本の井戸とその歷史. 地学雑誌, Vol. 60, No. 4, p. 183-190.

1951 菅原健 : 最近20年間の湖沼学の進歩. 科学, Vol. 21, p. 190-191.

1954 上野益三: 陸水学の75年. 地学雑誌, Vol. 63, No. 3, p. 41-46.

1961 高橋裕 : 水文学の成立と発達. 水利科学, 18 .

1961 斉藤仁 : 温泉の研究史と成因論 $(1)$ ，（2）。地下資源，No. 13， p. 35-38. No. 14, p. 1819. 
1963 蔵田延男：韋䭾天走りの工業用水一その歴史的回顧と未来像（2). 工業用水, No. 54，p. 614.

1963 鈴木静夫 :「日本の湖沼一湖沼学入門一」.内田老鶴围新社.

1963 堀江正治 :「日本の湖一その自然と科学一」. 日経新書.

1965 菅原健 :「たま沛ら」.

1965 猿橋勝子：日本の地球化学の現状. 化学の領域, Vol. 19, No. 4, p. 37-40.

1965 三宅泰雄 : 地球化学に㧍ける最近の動向について. 地学教育, No. 61, p. 11-13.

1966 日本温泉科学会 25 年の歩み. 温泉科学, Vol. 16, No. 3・4, p. 154-162.

1966 地質調查所地球化学課：地球化学. 地質ニュース, No. 137, p. 1-14.

1967 蔵田延男 : 昭和初期の地下水調查. 地学雑誌, Vol. 76, No. 6, p. 25-38.

1968 森田浩：日本に扔ける河川水温研究の科学史的背景と特徴。水温の研究, Vol. 11, No. 5, p. 1343-1351.

1968 松尾禎二：日本の地球化学. 日本地質学会編「日本の地質学」, p. 427-448.

1969 服部安蔵: わが国温泉50年の歩み. 温泉科学, Vol. 20, No. 3・4, p. 121-125.

1969 木村健二郎：本邦温泉の化学的研究に関する回顧．温泉化学，Vol. 20, No. 3・4, p. 135139.

1970 山本荘毅：地盤沈下とその研究. 地学雑誌, Vol. 78, No. 7, p. 23-33.

1970 地質調査所地球化学課編：日本の地球化学. 地質ニュース, No. 186, p. 1-25.

1970 半谷高久：地球化学の現状と課題. 日本の科学者, Vol. 5, No. 5, p. 16-21.

1971 井口昌平 : IHD のもとに扔ける日本の活動の展望. MTI/IHD/8/56.

1972 山本荘毅：水文学とは（日本水文学史）「「水文学総論」, 共立出版, p. 11-15.

1972 山本荘毅 : 水文学研究の動向 (英文). 地理学評論, Vol. 45, No. 2, p. 163-171.

1973 角清愛 : 伊豆下賀茂温泉のケースヒストリー（過去の事例の歷史的検討）。地質ニュース, No. 227 , p. $1-13$.

1974 竹内俊雄 : 流量調查の歴史一 - - 2-. 水利科学, Vol. 18, No. 3, p. 16-48. No. 4, p. 115-134.

\section{VI. 海 洋}

1916 「水路部沿革史」第一巻（1869-1885)，水路部.

1916 「水路部沿革史」付録上巻 (1869-1882). 水路部.

1916 「水路部沿革史」付録下巻 (1883-1885)。水路部。

1931 岡田駒吉 : 海路図の研究. 歴史地理, Vol. 58, No. 4.

1935 「水路部沿革史」第二巻 (1886-1926). 水路部.

1943 「水路部沿革史」第三巻 (1927-1941)。水路部.

1943 宇田道隆 :「新訂海の探究史」. 河出書房科学新書. 250 p.

1949 日高孝次：海洋物理学最近の進歩. 地学雑誌, Vol. 58, No. 6-7, p. 195-198.

1951 「水路部沿革史」第四巻 (1942-1945). 水路部。

1951 水路部創立80周年記念号. 水路要報, No. 25, p. 161-314,

1952 「水路部八十年の歴史」. 水路部, $274 \mathrm{p}$.

1954 宇田道隆 : 日本海洋学の進歩の足あと. 地学雑誌, Vol. 63 , No. 3, p. 35-40.

1955 沢田照夫：海水観測の歴史と現況。 天気，Vol. 2, No. 4.

1955 宇田道隆：「世界海洋探検史一海をひらく人々一」. 河出書房世界探検紀行全集，15，436 p. 
1956 田口龍雄: 「日本の海 海洋史料随想」. 古今書院, $192 \mathrm{p}$.

1960 宇田道隆 他：日本に打ける海洋調查の沿革と現状. 科学技術庁資源局.

1961 水路部創立 90 周年記念号. 水路要報, No. 67.

1961 日本海洋学会編: 日本海洋学会20年の歩み. 日本海洋学会, $213 \mathrm{p}$.

1964 大川相房 : 海図の変遷. 地図, Vol. 2, No. 2, P. 10-20.

1965 本学会の歩み. 日本海水学会誌, Vol. 19, No. 1, p. 67-68.

1965 城至成一: 大洋測深の移り変わり。水路要報, No. 80, p. 32-39.

1966 城至成一: 海軍時代の水路部海洋調查業務. 水路要報, No. 81, p. 49-60.

1968 日高孝次 :「海洋学との四十年」. 日本放送出版協会, $253 \mathrm{p}$.

1969 中西良夫 : 水路測量のはじまり 柳栖悦伝を中心に. 測量, Vol. 19, No. 7, p. 34-38.

1970 坊城俊厚 : 海域調查の回顧と展望（地質調查と測量特集）測量, Vol. 20, No. 2, p. 13-19.

1971 宇田道隆 :「海に生きて」. 東海大学出版会.

1971 川上喜代四：水路百年を迎えて. 地学雑誌, Vol. 80, No. 6, p. 42-44.

1971 海上保安庁水路部編：「日本水路史」(1871-1971)。 日本水路協会, 680 p. +16 p.

1971 水路部創立100周年記念号. 水路要報, No. 91.

1971 日本に㧍汸る海洋学最近 10年の歩み. 日本海洋学会誌, Vol. 27, No. 1（日本海洋学会創立 30周年記念号), p. 233-318.

1971 宇野木早苗 : 日本海洋学会最近10年の歩み. 日本海洋学会誌, Vol. 27, No. 6, p. 312-318.

1972 「東海大学海洋学部十年の歩み」. 東海大学海洋学部, 258 p.

1972 寺田一彦:「人間と海」. 丸ノ内出版。

1973 水野篤行 他：わが国および世界の海洋地質調查研究の動向 (2). 地地質ニニース, No. 223, p. 41-49.

1974 速水頌一郎先生御遺稿集出版事業会編 :「海洋時代」. 東海大学出版会.

\section{VII. 鉱業・鉱山}

1885 伊藤弥次郎：日本鉱山沿革考. 日本鉱業会誌, Vol. 1, No. 1, p. 3-8.

1887 松浦健二：半田銀山鉱業沿革志. 日本鉱業会誌, Vol. 3, No. 32, 33.

1888 大蔵省 :「工部省沿革報告」. $1100 \mathrm{p}$.

1890 山本勝太郎：金平金山沿革略記。日本鉱業会誌，Vol. 6, No. 67.

1891 和田維四郎：釷業の進歩. 日本鉱業会誌, Vol. 7. No. 71, p. 1-14.

1900 農商務省釷山局編 :「鉱山発達史」.

1902 足尾銅山の沿革. 日本釷業会誌, Vol. 18, No. 208.

1903 渡辺渡 : 本邦鉱業進歩の概況。日本鉱業会誌, Vol. 19, No. 219.

1903 大塚専一：石油事業発達の概況. 日本鉱業会誌, Vol. 19, No. 220.

1906 横堀治三郎：鉱業界の進歩の趨勢. 日本釷業会誌, Vol. 22, No. 254, 255.

1907 渡辺渡 : 東西古今の山相学を論ず. 日本鉱業会誌, Vol. 23, No. 272.

1911 東京鉱山監督署編 :「日本鉱業誌」

1911 西尾銈次郎：維新以前に於ける本邦の鉱業. 日本釷業会誌，Vol. 27，No. 312，313，315， 317-318.

1917 吉田東伍：江戸時代の鉱山業に就いて． 日本鉱業会誌，Vol. 33，No. 383， p. 27-48. No. 384, p. 127-137.

1918 上野景明：明治以前に於ける北海道鉱業の発達．日本鉱業会誌，Vol. 34，No. 406，p. 1149- 
1165.

1918 坂市太郎：北海道の開発と石炭鉱業。日本釷業会誌, Vol. 34, No. 403，p. 844-852.

1921 22 西尾銈次郎：古代に於ける鉱山技術の研究. 日本鉱業会誌, Vol. 37, No. 434-435.

Vol. 38, No. 452-454.

1923 24 西尾銈次郎：日本古代鉱業史要. 日本鉱業会誌，Vol. 39， No. 460， p. 440-454. Vol.

40, No. 468 , p. $169-188$.

1926 水田政吉 : 本邦製油業の進歩. 日本鉱業会誌, Vol. 42, No. 7 .

1927 宮崎虎一：日本に於ける採釷治金の発達. 科学画報臨時增刊, 日本の科学界, p. 148-154.

1929 永積純次郎：我国に於ける炭砝技術の進歩。日本鉱業会誌，Vol. 45，No. 535， p. 765-785.

1932 鉱山懇話会編：「日本釷業発達史」. 上巻, 933 p. 中巻, 806 p. 下巻, 1015 p.

1935 日本釷業会編 :「日本鉱業会の五十年」. $53 \mathrm{p}$.

1939 後閑文之助：日本産金史話ところどころ. 科学知識, Vol. 19, No. 8, p. 96-101.

1941 住友本社 :「別子開坑二百五十年史話」.

1943 西尾銈次郎 :「日本鉱業史要」。一組出版社, $188 \mathrm{p}$.

1947 佐野秀之助：昔の炭坑と今の炭坑. 地球の科学, Vol. 2, No. 3, p. 1-7.

1949 日鉄鉱業株式会社編 :「創立拾年史」.

1950 「八幡製鉄所五十年誌」. $473 \mathrm{p}$.

1952 嘉屋実編 :「日立鉱山史」.

1953 最近の石油技術の進歩. 石油技術協会誌，Vol. 18，No. 4 (創立20周年記念特別号)， 325 p.

1953 池上隆 他：日本石油鈗業史A 油田開発史. 石油技術協会誌，Vol. 18，No. 4, p. 5-20.

1953 植村武治 他: 日本石油釷業史 B 鳌井採油技術史. 石油技術協会誌, Vol. 18, No. 4, p. 21-24.

1955 同和鈗業株式会社 :「七十年之回顧」. 同社, $290 \mathrm{p}$.

1955 「釜石製鉄所七十年史」. $533 \mathrm{p}$.

1956 麓三郎 :「佐渡金銀山史話」. 三菱金属鉱業株式会社, 573 p. +7 p.

1956 小葉田淳 :「鉱山の歴史」. 至文堂日本歴史新書, $220 \mathrm{p}$.

1957 三枝博音・飯田賢一：「日本近代製鉄技術発達史一八幡製鉄所の確立過程一」。東洋経済新報社， 716p. +36 p.

1958 日本学士院編：「明治前日本鉣業技術発達史」. 岩波書店.

1958 「本石油史」(創立七十年記念)。日本石油株式会社, 630 p.

1958 「北海道炭砇汽船株式会社七十年史」. 本文 $731 \mathrm{p}$. 資料 $104 \mathrm{p}$.

1961 「秋田鉱山専門学校・秋田大学鉣山学部50年史」.

1962 大町北一郎：わが国の鉄釷業と製鉄業の生いたち. 地質ニュース，No. 95，p. 28-42.

1963 椎名清: 茂原ガス田について一主として関東天然瓦斯開発(株)の天然ガス開発の歷史と現況一.

天然ガス, Vol. 6, No. 5, p. 26-29.

1963 矢嶋澄策：日本水銀鉱床の史的考察．地学雑誌，Vol. 72, No. 4, p. 28-38.

1964 麓三郎 :「尾去沢・白根鈗山史一近世銅鈗業史の研究一」. 勁草書房, 440 p. 索引 7 p.

1965 日本科学史学会 :「採釷治金技術」. 日本科学技術史大系, 第 20 巻, 第一法規出版, $601 \mathrm{p}$.

1966 橋本謙一：筀業協会75年の歩み。 セラミックス, Vol. 1, No. 10, p. 795-805.

1966 石灰石鉱業の歩み. 石灰石, No. 104，(石灰石鉱業協会設立20周年記念特集), p. 189-340.

1966 採鉣技術の変遷。石灰石, No. 104，p. 203-213.

1967 通産省臨時石炭対策本部・福岡通商局石炭部共編：九州石炭鉱業20年の歩み. $411 \mathrm{p}$.

1967 「茂尻炭矿五十年史」. 雄別炭鉱茂尻鉱業所, 410 p. 
1967 「石油資源開発株式会社十年史」. $301 \mathrm{p}$.

1968 小葉田淳 : 近世鉱山史の概要. 三井金属修史論叢, 1, p. 5-10.

1968 69 目崎憲司：日本金属発展史序説一1，2-，追手門経済論集，Vol. 3， No. 1, p. 1-31.

Vol. 4, No. 2, p. 1-47.

1968 青山龍作：日石八十年の歴史によせて. 石油産業, Vol. 4, No. 5, p. 30-34.

1968 日本石油沿革概要. 石油産業, Vol. 4, No. 9, p. 16-23.

1968 日本鉱業協会20年略史. 鉱山, Vol. 21 , No. 8, p. 8-45.

1968 黒川真武 : 燃料協会の 45年をかえりみて. 燃料協会誌, Vol. 47, No. 489, p. 4-12.

1968 小葉田淳 :「日本鉱山史の研究」. 岩波書店, 760 p. +32 p.

1968 道家欽: 鉱業明治百年. 石灰石, No. 112, p. 62-65.

1968 渡辺萬次郎 :「鉱山史話一東北編」. 地下の科学シリーズ, ラテイス, $214 \mathrm{p}$.

1968 津村光信：わが国石油鉱業の十五年. 石油文化. Vol. 16, No. 10, p. 31-42.

1969 木下亀城:「鉱山史話一九州編」. 地下の科学シリーズ, ラテイス, $197 \mathrm{p}$.

1969 上田彰: 徳川時代の宇部炭田. 中国炭鉱技術会誌，Vol. 21，No. 2, p. 3367-3374.

1969 永井彰一郎 : 石膏石灰学会創立から約 20 年の 追憶 (石高と石灰誌第百号を記念して). 石高と 石灰, No. 100, p. 95-98.

1970 佐々木享 : 日本鉱業会の創立をめぐつて. 専修自然科学紀要, 3, p. 31-44.

1970 大矢真一：室町時代の釷業技術。技術史談会資料， 6, p. 1-5.

1970 小葉田淳 : 摄津, 多田銀銅山史の研究. 竜谷大学論集, 393, p. 1-5.

1970 寺島敏治 : 明治三十年代初頭での釧路地方の鉱業について, 特に安田の経営する硫黄山と炭山 を中心に. 日本歴史, 268, p. 38-56.

1970 「住友金属釷山二十年史」. 住友金属鉱山株式会社, 389 p. 年表 35 p.

1970 「帝国鈗業開発株式会社史」. 金子出版, $428 \mathrm{p}$.

1970 三井金属鉱業修史委員会編 :「神岡鉱山史」. 728 p. 同「史料」. $221 \mathrm{p}$.

1971 日本鉱業会誌1000号記念 (特集). 日本鉱業会誌, Vol. 87, No. 1000, p. 437-458.

1971 佐々木享：日本鉱業会創立の意義と背景. 日本鉱業会誌, Vol. 87, No. 1000, p. 445-448.

1971 三川逸郎 : 京葉地帯の天然ガス開発の歩み (1). 天然ガス, Vol. 14, No. 1, p. 34-38. Vol. 14, No. 7, p. 23-27.

1971 大坪忠一：佐渡鉱山の今昔 佐渡金山の歴史と 鉱山測量の沿革. 測量, Vol. 21, No. 1, p. 33-41.

1971 日鉄鉱業株式会社：「日鉄鉱業株式会社三十年の歩み 昭和14年-44年」. $528 \mathrm{p}$.

1973 「日本の石油鉱業と技術一石油技術協会40周年記念一」. 石油技術協会, $430 \mathrm{p}$.

1973 麓三郎 :「佐渡金銀山史話」増補版。三菱金属鉱業株式会社.

1973 「秋田大学釷山学部六十年史」. 財界評論社, $712 \mathrm{p}$.

1974 福田理 : 石油産業発祥地記念公園と石油記念館. 地質ニュース, No. 244, p. 22-29.

1975 岸本文男 : 伊勢の国丹生の水銀. 地質ニュース, No. 251, p. 24-33.

1975 大橋周治 :「幕末明治製鉄史」.アグネ, $332 \mathrm{p}$.

\section{VIII. 海 外 関 係}

1924 Ahnert, E.: Geological Investigation in Manchuria. Bull. Geol. Soc. China, Vol. 3.

1926 Kawasaki, S.: Geology of Korea. Third Pan-Pacific Science Congress, Tokyo.,

"Scientific Japan, Past and Present", p. 72-76. 
1926 KRYstfovich, A.: Geology; Pacific Russian Scientific Investigations.

1927 「中国地質調查所記略」.

1930 川崎繁太郎：古文献に顕はれたる朝鮮鈗物の名称. 朝鮮薬学雑誌, No. 4, p. 209-231.

1931 “The National Geological survey of China 1916-1931: A Summary of its Establishment. 30 p. (中国地質調査所概況 : 本所成立十五周年記念刊. 中華民国二十年三月).

1933 立岩嚴編 :「朝鮮に於ける地質及鉱物の調查沿革並文献」。朝鮮鉱業会, $129 \mathrm{p}$.

1933 小川环治 : 支那古代地理学史. 岩波講座, 「地理学」(総論), $47 \mathrm{p}$.

1934 石井清彦: 中央アジア探検略史 (其 1一其 3). 地学雑誌, Vol. 46, No. 548, 549, 550.

1935 朝鮮総督府地質調查所出版物目録, 昭和10年 4 月現在. $12 \mathrm{p}$.

1935 楊遵儀:「中国地質文献目録」. 国立北平研究院総弁事処出版課, $241 \mathrm{p}$.

1936 計栄森:「中国科学著作目録」、第五組，地質学．中国中央研究院評議会，57 p.

1938 王庸 :「中国地理学史」.

1939 立岩膂編 : 朝鮮地質及釷物文献目録（II). 朝鮮鉱業会, 26 p. 追加 2 p.

1939 満洲帝国国務院大陸科学院地質調查所要覧. $22 \mathrm{p}$.

1939 遠藤隆次 : 満洲に於ける地質研究の歴史.「改訂増補 満洲の地質及鈗産」，三省堂， p. 1-6.

1939 早坂一郎 : 台湾化石研究史略. 台湾総督府博物館創立三十年記念論文集.

1939 「地質調査所三十一年史」。満洲帝国地質調査所, $192 \mathrm{p}$.

1939 40 満洲地質関係文献集録その 1, その 2 . 満洲地質調查所報告, No. 98, No. 99.

1940 津田秀郎編：昭和 14 年朝鮮地質鉣物文献目録．朝鮮総督府地質調查所雑報，No６， p. 4551.

1940 高木㐘三郎 : 支那地図概観。地学雑誌, Vol. 52, No. 622, p. 577-588.

1941 満洲帝国国務院大陸科学院地質調查所要覧. 22 p.

1941 津田秀郎：昭和15年朝鮮地質釷物文献目録. 朝鮮総督府地質調查所雑報, No. 8, p. 41-47.

$1941 \cdot 43 \cdot 44$ 満洲地質関係文献集録 其の 3 ，其の 4 ，其の 5 。満洲地質調查所彙報，No. 102, 108, 109 .

1942 「海自然科学研究所十周年記念誌」付出版物目録. 228 p.

1942 無名氏 : 昭和 16 年朝鮮地質釷物文献目録。朝鮮総督府地質調查所雑報, No. 11, p. 50-57.

1942 文部省編：「東亜共栄圈資源科学文献目録 仏領印度支那 - 泰国」. 岩波書店, 259 足. 付録,

$81 \mathrm{p}$.

1942 文部省編：「東亜共栄圈資源科学文献目録 ニウギニア」. 岩波書店, $253 \mathrm{p}$. 付録 $81 \mathrm{p}$.

1942 「東亜共栄圈資源科学文献目録 フィリピン」. 資源科学研究所, $382 \mathrm{p}$. 付録 $61 \mathrm{p}$.

1943 「東亜共栄圈資源科学文献目録 馬来半島」. 資源科学研究所, $241 \mathrm{p}$. 付録 $11 \mathrm{p}$.

1943 章鴻釗著, 前田隆良・熊谷喜之訳 :「支那地質学発展史」. 支那文化叢書, 人文閣, 202 p. 人名 索引 $11 \mathrm{p}$.

1943 芳賀雄 : 「支那鉱業史」. 電通出版部. $365 \mathrm{p}$.

1943 満鉄調查局編 : 「支那釷産資源文献目録」. 博文館, $88 \mathrm{p}$.

1943 E. アーネルト:「満洲地質探検行」. 武蔵書房, 275 p.

1943 「地学連合満洲大会報告及講演集」. 日本地質学会 - 日本岩石砿物鈗床学会 - 日本地理学会 - 満 洲地質協会, $182 \mathrm{p}$.

1944 洪以㯆 :「朝鮮科学史」. 三省堂, $452 \mathrm{p}$.

1947 顔滄波・何春孫・陳培源：「台湾地質文献」. 台湾省地質調查所, 58 p.

1949 坂本峻雄: 満洲の地質. 地球の科学, Vol. 4, No. 2, p. 7-19. 
1953 Teves, J. S.: Bibliography of Philippine Geology, Mining and Mining Resources. Republic of the Philippines, Department of Agriculture and Natural Resources, Bureau of Mines, Bibliography Series No. 1, 155 p.

1955 高橋英太郎：朝鮮地質研究史補遗. 地学研究, Vol. 8, No. 1, p. 26-29.

1955 笹倉正夫：中共に㧍ける地質事業発展の動向. 日本鉱業会誌, Vol. 71, No. 803, p. 241-245.

1956 TateiwA, I. : Corée-Korea-. Lexique Stratigraphique International, Vol. III, Asie, Fascicule 2 a, 83 p. 1 map.

1956 Uemura, K.: Mandchourie-Manchuria-. Ibid. Vol. III, Fascicule 2 b. 68 p. 1 map.

1956 王庸 :「中国地理図籍叢考」。商務印書館, 180 p.

1956 Inteligence Division, Office of the Engineer, Headquarters U.S. Army Forces Far East and Eighth U.S. Army with Personnel of the United States Geological Survey: Annoted Bibliography of Geologic and Soils Literature of Western North Pacific Islands.

1956 小林貞一：東亜地質の探究略史と文献.「東里地質」上巻, 朝倉書店, p. 247-253.

1957, 1960 小林貞一: 中国に 於汀最近の古生物学研究 $(1 \sim 2)$. 地質学雑誌, Vol. 63, No.

748, p. 485-492. Vol. 66, No. 781, p. 675-680.

1958 王庸:「中国地図史綱」.

1963 Buravas, S. : Progress in Geology and Geophysics in Thailand since the First Pacific Science Congress. 地学雑誌, Vol. 72, No. 2, p. 94-98.

1964 橋本亘：中華民国台湾省で刊行された地質に関する文献の紹介（I-II）. 地学雑誌，Vol. 73，

No. 5, p. 309-316. No. 6, p. 366-376.

1964 全国地層委員会:「全国地層会議 学術報告彙編」. 12巻, 科学出版社. (中国的前寒武系 寒武

系, 奥陶系, 志留系, 泥盈系, 石炭系, 二畳系, 睌古生代陸相地層, 三盢系, 侏羅系和白亜系,

中生代陸相地層, 新生界)

1964 保柳睦美 : 日本の学者による中国本土に関する地理学的研究著書・資料・論文目録 (1935-1950).

付 1 , 朝鮮半島, 台湾に関する地理学的研究論文目録. 付 2 , 中国本土に関し欧文で発表された

抢もな地理学的著書・論文目録. 東京地学協会, $109 \mathrm{p}$.

1965 遠藤隆次 : 満洲に招ける地質研究略史. 東亜地質釷産誌, 満洲之部.

1965 立岩彂：朝鮮に於ける地質研究の歴史. 東亜地質釷産誌, 朝鮮之部.

1965 小倉勉：満洲国地質調查所の沿革．東亜地質鉱産誌，満洲之部。

1965 坂本峻雄 : 南満洲鉄道株式会社調查局鉱産地質調查室の調查史. 東亜地質鉱産誌, 満洲之部.

1965 三田正一：満洲鉱業開発株式会社鉱産資源調查所の沿革。東亜地質鉱産誌，満洲之部。

1965 尾崎博：満洲鈗山株式会社の歷史．東亜地質鉱産誌，満洲之部。

1965 染谷二男 : 東辺道開発株式会社調査開発史. 東亜地質鉱産誌, 満洲之部.

1965 小倉勉 : 満洲国地質調查所の沿革. 東亜地質鉱産誌，満洲之部。

1965 赤瀬川安彦：満洲に於ける鉱業の沿革. 東亜地質鉱産誌，満洲之部.

1965 赤瀬川安彦: 満洲採金株式会社の調查研究略史. 東亜地質鉱産誌, 満洲之部.

1965 遠藤隆次 :「原人発掘一一古生物学者の満洲 25 年一」. 春秋社, $182 \mathrm{p}$.

1966 尹賛勲・周明鎮・徐仁：中国における古生物学の進歩. 地球科学, No. 77, p. 36-39.

1967 吉野正敏：昭和時代の日本に抢ける探検と海外調查の歴史. 東京教育大学地理学研究報告, 11 , p. $159-178$.

1968 波多江信広：「西イリアンの思い出」. 川島書店. $210 \mathrm{p}$.

1968 - 70 GobBET, D. J. : Bibliography and Index of the Geology of West Malaysia and 
Singapore. Geological Society of Malaysia, Bull. No. 2, p. 152, No. 3, p. 115-129. 1969 小林貞一：本協会の支那地学調查の概要。地学雑誌, Vol. 78, No. 3, p. 53-58.

1969 野田勢次郎：中支那及南支那地学調查の回想（自大正元年至同 4 年）。地学雑誌，Vol. 78, No. 3, p. 59-66.

1969 早坂一郎 : 支那地学調查（自明治 44 年至大正 5 年）報告書第三巻 (大正 9 年)。地学雑誌, Vol. 78 , No. 3, p. 67-70.

1969 植村癸巳男・坂本峻雄 : 東亜地質鉱産誌編集委員会. 地学雑誌, Vol. 78, No. 3, p. 71-93.

1971 深田久弥：「中央アジア探検史」. 白水社西域探検紀行全集別冊, $562 \mathrm{p}$.

1971，75 東南アジア古生物研究会：「東南アジア古生物の研究」についての記録。地学雑誌，Vol. 80 , No. 1 , p. 18-35. Vol. 84 , No. 3, p. 42-59.

1971 多田文男 : 朝鮮半島の地形研究史の一端. 地理, Vol. 16, No. 11.

1973 斉藤正次 : 太平洋戦争時の南方地質調查始末記.「鈴木醇一人とその背景一」, p. 126-137.

1974 保柳睦美：解放後の中国における地理学研究の動向. 地学雑誌, Vol. 83, No. 6, p. 22-37.

1975 多田文男 : 日本の地理学者による中国に関する学術調查. 駒沢地理, No. 11.

1976 坂本峻雄 : 東亜地質釷産誌編集委員会. 地学雑誌, Vol. 85, No. 1, p. 43-60.

1976 立石廙：「朝鮮一日本列島地帯地質構造論考一朝鮮地質調查研究史一」. 東京大学出版会, 680 p. 写真・図版 137 .

\section{IX. 地学教育・地学全般}

1930 小藤文次郎：地学雑誌の由来. 地学雑誌, Vol. 42, No. 500, p. 562-563.

1930 横山又次郎 : 地学雑誌の今昔. 地学雑誌, Vol. 42, No. 500, p. 564-567.

1930 鈴木敏 : 東京地学協会と地学俱楽部. 地学雑誌, Vol. 42, No. 500, p. 568-570.

1930 小川环治 : 地学雑誌創刊以来42年間の本邦地学会の回顧と前途の希望. 地学雑誌, Vol. 42 , No. 500 , p. $574-578$.

1930 「東京地学協会沿革誌」. 付 出版物目録. 東京地学協会, $35 \mathrm{p}$.

1936 藤本治義：理科教育に於ける地質鉱物科，日本学術協会，Vol. 1, No. 12，p. 148 .

1937 Fujimoto, H. : Geology and Mineralogy. Science Education in Japan, p. 54-68.

1938 藤本治義 : 時勢に鑑て地質鉱物科教育の振興をはかれ。理学界，6・7 月.

1954 大井上義親：東京地学協会の沿革. 地学雑誌，Vol. 63，No. 3 (創立75周年記念特別号), p. $1-11$.

1956 中山元 : 地学教育の歷史. 地学教育講座, 15, 「地学の研究史と教育史・地学教育の目標」, 福 村書店, p. 66-77.

1958 関和一郎：地学教育の変遷. 地学, No. 32, p. 5-16.

1958 関和一郎 : 地学教育の変遷と課題.「藤本治義教授還暦記念論文集」, p. 478-484.

1962 小林貞一：日本地学教育研究会の思、出と将来への私の希望. 地学教育, No. 48, p. 1 .

1963 日本地学教育研究会 : 地学教育の歩み. 「地学教育の課題」, ダイヤモンド社, p. 3-24.

1965 日本科学史学会:「地球宇宙科学」. 日本科学技術史大系, 14巻, 第一法規出版, $661 \mathrm{p}$.

1966 渡部景隆：日本地学教育学会の歩み一日本地学教育研究会設立を中心として一. 地学教育,

No. 66 , p. 1-8.

1966 日本地学教育研究会編：日本地学教育学会年表. 地学教育, No. 66, p. 8-15.

1966 鹿沼茂三郎 他: 藤本先生と地学教育. 地学教育, No. 66, p. 68-70.

1968 渡部景隆 : 日本の地学教育制度の変遷と目標の研究。地学教育, No. 75, p. 121. 
1969 石田龍次郎 : 東京地学協会編年史稿. 地学雑誌, Vol. 78, No. 3 (東京地学協会 90 年史), p. 1-11.

1969 蒲生英男 :「日本理科教育小史」. 国土社, $188 \mathrm{p}$.

1970 Hirayama K.: History of the Earth Sciences in Japan. Atlas, Vol. 6, No. 3, p. 7475.

1970 71 中川浩一: 教科書からみた地理教育の歴史。地理，Vol. 15，No. 1-4，No. 6-7，No. 911. Vol. 16, No. 1-12.

1971 石田龍次郎：東京地学協会編年史稿. 補遺. 地学雑誌, Vol. 80, No. 1, p. 36-45.

1971 中川浩一：明治期における地図教育の推移一 1 -2 一. 地図, Vol. 9, No. 3, p. 1-7. No. 4 , p. $1-7$.

1974 渡部景隆: 従来の地学教育研究. 地学研究, No. 112-113, p. 154-160.

1974 伊木正二：鉱山系大学教育問題研究委員会報告. 日本釷業会誌, Vol. 90, No. 1036, p. 419.

\section{X. 科学史一般・大学関係・博物館など}

1875 76 「東京開成学校一覧」.

1877 大槻如電 :「日本洋学年表」。

1880 84「東京大学法理文三学部一筧」. No. 1-4.

1891 白井光太郎 :「日本博物学年表」. $86 \mathrm{p}$.

1908 白井光太郎：「増訂日本博物学年表」. $220 \mathrm{p}$.

1917 大日本文明協会編：「日本の科学界」. $415 \mathrm{p}$.

1925 31 工学会編 :「明治工業史」. 全10巻, 丸善, (鉱業編, 機械・地学編を含む).

1926 Third Pan-Pacific Congress, Science Tokyo, Publishing Committee: Learned institutions, Its "Scientific Japan, Past and Present". p. 311-359.

1926 「新日本史」. 万朝報社, (第 3 巻は桑木或雄の物理学篇, 小川环治の地理学篇, 今村明恒の地 震学篇)

1926 「北海道帝国大学沿草史」(創基五十年記念). $303 \mathrm{p}+36 \mathrm{p}$.

1927 大槻如電 :「新撰洋学年表」。

1931 明治史講座刊行会編：「明治科学史」. 大阪宝文館。（地質編は江原真伍）

1931 加藤武夫 :「太平洋学術会議」. 岩波講座, 地質学及び古生物学 砝物学及び岩石学 (別項), 30 p.

1932 「東京帝国大学五十年史」.上冊, 1427 p. 下冊, 1333 p.

1934 東京科学博物館編 :「江戸時代の科学」. 博文館, 345 p.

1934 白井光太郎 :「改訂増補日本博物学年表」. 大岡山書店.

1937 寺島柾史 :「日本科学発達史」. 啓文社。

1939 冨成貴馬平 :「日本科学史要」. 弘文堂, $169 \mathrm{p}$.

1940 「東京工業大学六十年史」.

1941 冨成貴馬平:「現代日本科学史」. 三笠書房.

1942 石原純：「科学史」. 現代日本文明史. 第十三巻，東洋経済新報社出版部， $489 \mathrm{p}$.

1942 東京帝国大学編: 「東京帝国大学学術大観, 理学部・東京天文台・地震研究所篇」. $682 \mathrm{p}$.

1943 帝国学士院 :「帝国学士院六十年史」.

1943 「京都帝国大学史」.

1948 上野益三 :「日本博物学史」. 星野書店.

1954 矢島祐利編 :「明治文化史学術編 自然科学」. 洋々社. 
1956 菅井準一他編：「科学技術史年表 第 $\mathrm{V}$ 篇 日本」. 平凡社.

1957 「鉄道技術研究所五十年史」.

1960 「東北大学五十年史」. 2 冊.

1961 湯浅光朝:「科学史」. 日本現代史大系, 東洋経済新報社, 379 p.

1961 湯浅光朝編 : 「現代日本科学技術史年表」. 三一書房, $277 \mathrm{p}$.

1962 矢島祐利・関野克監修：「日本科学技術史」。朝日新聞社, $908 \mathrm{p}$.

1962 国立科学博物館85周年記念号. 自然科学々博物館, Vol. 29, No. 9-10, 126 p.

1962 日高孝次 : 太平洋学術会議と太平洋学術協会. 地学雑誌, Vol. 71, No. 2.

1962 63 日本学士院:「日本学士院八十年史」. 5 冊.

1964 日本科学史学会 : 「通史 1 幕末 ・明治初期1853-1889」。通史 5 昭和後期1945-1960」。本科学 技術史大系 第 1 , 第 5 巻, 第一法規.

1964 日本学術会議：「全国研究機関総覧」. 昭和 39 年版.

1964 日本学士院:「明治前日本物理化学史」. 日本学術振興会, $645 \mathrm{p}$.

1965 太秦康光 : 北大理学部創生記. 自然, Vol. 20 , . No. 5, p. 72-76.

1965 仁田勇 : 阪大理学部創設のころ. 自然, Vol. 20, No. 5, p. 77-81.

1965 近藤基吉 : 九大理学部創設と社会事情. 自然, Vol. 20, No. 5, p. 82-86.

1965 菅原健 : 名大理学部生い立ちの記. 自然, Vol. 20, No. 5, p. 87-91.

1965 広重徹 : 日本の大学の理学部一その科学社会史的側面. 自然, Vol. 20, No. 5, p. 92-111.

1965 武村重和: 東京開成学校と外人科学者 (日本自然科学教育成立史研究一 - -). 広島大学教育 学部紀要 (1), No. 14, p. 27-38.

1965 日本学術会議 :「全国学協会総覧」。昭和41年版.

1966 「科学技術庁十年史」. 599 p.

1966 「科学技術庁金属材料研究所十年の歩み」. $188 \mathrm{p}$.

1966 初山有恒：苦難をこえて25年一資源科学研究所の場合一. 科学朝日, No. 11, p. 42-45.

1967 日本学士院：「日本学士院一覧, 自昭和 34 年至昭和 41 年」. $406 \mathrm{p}$.

1967 杉野目晴貞 : 北海道大学の歩み. 土木学会誌, Vol. 51, No. 3, p. 47-51.

1967 東京大学物性研究所 :「物性科学々は一物性研究所 10 年の歩み一」. $222 \mathrm{p}$.

1967 東北大農研班: 学術振興会の歴史. 日本の科学者, Vol. 2, No. 3, p. 58-63.

1967 日本科学史学会：「通史 2 明治期 1889-1914」. 「通史 3 大正期 1914-1930」. 「通史 4 昭和前期 1930-1945」. 日本科学技術史大系, 第 $2 \cdot 3 \cdot 4$ 巻, 第一法規出版.

1967 国立科学博物館開館90周年記念誌. 自然科学と博物館, Vol. 34 , No. 11-12, 370 p.

1968 「国立防災科学技術センター五年のあゆみ」. $95 \mathrm{p}$.

1968 年表学術会議のあしどり. 科学朝日, Vol. 28 , No. 4 日本学術会議の 20 年 (特集), p. 4650.

1968 福島要一・牛来正夫両会員に日本学術会議 20 年の歩みを聞く. 日本の科学者, Vol. 3 , No. 1 , p. 2-19.

1968 上野益三:「打雇、外国人 (3) 自然科学」. 鹿島研究所出版会, $258 \mathrm{p}$.

1968 日本科学史学会: 「自然」. 日本科学技術史大系, 第11巻, 第一法規出版.

1970 北川敏男 :「科学計画への道 日本学術会議の十七年」. 共立出版, $363 \mathrm{p}$.

1970 大矢真一：日本科学史 (展望). 科学史研究 (II), Vol. 9. No. 95, p. 129-138.

1971 「京都大学防災研究所二十年史」. $217 \mathrm{p}$.

1971 岩城正夫 : 日本科学史学会30年の歩み. 科学史研究 (II), Vol. 10, No. 100, p. 195-201. 
1972 福田繁：九十五周年を迎えて. 国立科学博物館ニュース, No. 11, p. 1-5.

1973 国立国会図書館整理部編：「国立国会図書館所蔵明治期刊行図書目録 第 3 巻 自然科学 - 医 学・農学・工学・家事・芸術・体育・諸芸の部」. 国立国会図書館, $863 \mathrm{p}$.

1973 上野益三:「日本博物学史」. 平凡社. $680 \mathrm{p}$. 索引73 p.

1974 日本学術会議 25 周年記念特集. 日本学術会議月報, Vol. 15, No. 1.

1974 日本学術会議編 :「日本学術会議25年史」. $606 \mathrm{p}$.

1974 鶴田総一郎 他: 自然史博物館一の招待（特集）。自然科学と博物館, Vol. 41, No. 4, p. 137-184.

1974 玉虫文一 他:「原典による自然科学の歩み」。講談社, 537 p. +11 p.

1974 総合学生問題研究所 :「大学大鑑1974, 特集大学百年史」. 日本学術通信社, $592 \mathrm{p}$.

1975 「北大工学部五十年史」. 北大工学部創立五十周年記念事業会, $475 \mathrm{p}$.

(1976年 5 月28日受理) 